\title{
Sovereign Risk and Government Change: Elections, Ideology and Experience*
}

\author{
Sarah M. Brooks ${ }^{\dagger}$ \\ Raphael Cunha ${ }^{\ddagger}$ \\ Layna Mosley ${ }^{\S}$
}

August 2021

\begin{abstract}
Global capital markets can react dramatically to elections in developing countries, affecting governments' access to finance and sometimes setting off broader crises. We argue, contrary to some conventional wisdom, that investors do not systematically react to the election of left-leaning parties and candidates. Government ideology is often an imprecise heuristic, given the diversity in policies among parties, especially those on the left. We therefore expect that neither elections generally, nor elections that produce specific partisan outcomes, are associated with significant changes in sovereign financing costs. Yet we also predict that the election of left-leaning parties will generate volatility in sovereign bond markets, reflecting investors' uncertainty over future policy outcomes. This volatility is especially pronounced when new governments take office; over time, however, government policy performance enables investors to make increasingly precise estimates of political risk. Volatility has implications for the real economy, as well as for governments' ability to manage their debt. We test, and find support for, our core expectations using monthly data on sovereign bond spreads and credit default swap prices for 74 developing countries from 1994-2015.
\end{abstract}

${ }^{*}$ Data and supporting materials necessary to reproduce the results in the article are available in the CPS Dataverse: https://doi.org/10.7910/DVN/WJGJQ7 (Brooks, Cunha, and Mosley, 2021). For comments on previous versions of this paper, we thank participants in the Princeton Niehaus Center Political Economy Workshop (March 2018, Da Nang, Vietnam); the 2017 meeting of the International Political Economy Society; the Financial Crisis Management and its Consequences in Comparative Perspective workshop (April 2016, Freie Universität Berlin); and the Political Economy of International Organization meeting, University of Salzburg (February 2019). We are also grateful to the anonymous reviewers at CPS.

${ }^{\dagger}$ Ohio State University. Email: brooks.317@osu.edu.

${ }^{\ddagger}$ Florida State University. Email: rcunha@fsu.edu.

${ }^{\$}$ Princeton University. Email: layna.mosley@princeton.edu. 
In an era of financial globalization, market responses to elections can dramatically affect governments' financing capabilities, as well as the cost of capital throughout the economy. Elections may generate uncertainty not only about who will win, but also about which coalition will govern and which policies the new government will adopt. In developing and advanced industrial nations alike, elections have generated foreign exchange speculation (Bernhard and Leblang, 2006; Eichengreen et al., 1995; Leblang, 2002); declines in sovereign credit ratings (Block and Vaaler, 2004; Vaaler, Schrage, and Block, 2006); increased spreads on sovereign debt (Martínez and Santiso, 2003; Block and Vaaler, 2004; Vaaler, Schrage, and Block, 2005); and stock market volatility (Jensen and Schmith, 2005; Leblang and Mukherjee, 2005). Like broader macroeconomic volatility and capital flight, volatility in government financing costs can impose significant welfare costs on developing countries as government investment and spending are curbed, threatening growth as consumption shocks reverberate through the economy (Loayza et al., 2007; Pastor, 1990). Market reactions can be particularly notable when elections result in partisan switches, perhaps implying significant policy changes (Sattler, 2013). Left-leaning governments are more likely to defend their currencies from speculative attacks, while right-leaning governments are associated with looser bank regulation (Broz, 2013; Walter, 2009). Investors in government bonds may worry that left governments will raise taxes, inflate the economy or even default on sovereign debt. If these expectations generate negative market reactions, newly-elected governments may be tempted to reverse their policies, sometimes dramatically.

Yet even when elections result in partisan switches or victories for left-leaning governments, they do not always generate negative market reactions. Indeed, as we demonstrate below, most national elections in developing countries are not associated with abnormal bond market returns. We therefore offer a more nuanced assessment of the causal channels through which elections affect investors' risk assessments. We theorize that government partisanship is not a consistently useful information shortcut for investors. Rather, the partisan signal is noisy: there is significant macroeconomic policy heterogeneity among left-leaning political parties. As a result, left-leaning governments will not pay systematically higher borrowing costs than their right-leaning counterparts.

At the same time, elections and partisan shifts do increase investors' uncertainty regarding future 
government policy, especially for newly-elected left-leaning governments. Uncertainty among investors regarding the course of future policy generates greater volatility in sovereign bond pricing for newlyelected left governments. Volatility can have important consequences for government debt management, as well as for broader economic outcomes. As government time in office increases, investors are better able to form expectations regarding future policies, and volatility decreases. We test our claims using data from 74 emerging market countries between 1994 and 2015. Our analyses, which support our core empirical predictions, further our understanding of the precise linkages between domestic politics and international financial markets.

\section{Markets, Elections and Political Risk}

Investors in sovereign debt are closely attuned to default, as well as inflation and currency, risk (Eaton and Gersovitz, 1981; Eichengreen and Hausmann, 2005; Tomz and Wright, 2013). Although developing countries' access to capital markets is driven partly by global and regional factors (Brooks, Cunha, and Mosley, 2015; Gray, 2013; Longstaff et al., 2011; Ballard-Rosa, Mosley, and Wellhausen, 2021), country-specific factors play a central role. When evaluating sovereign risk, investors consider governments' ability, as well as their willingness, to pay. Ability to pay typically is associated with macroeconomic fundamentals, including public debt, current account position, and reserve holdings, as well as with monetary and fiscal institutions (Bodea and Hicks, 2015; Mosley, 2003). Investors also may reward financial and economic transparency (Copelovitch, Gandrud, and Hallerberg, 2018). Willingness to pay, on the other, hand, usually is associated with domestic political institutions. For instance, democratic regime structures may encourage respect for loan contracts; constrain executive fiscal authority; impose greater audience costs for default; and facilitate greater economic transparency (e.g. Archer, Biglaiser, and DeRouen, 2007; Beaulieu, Cox, and Saiegh, 2012; Biglaiser and Staats, 2012; Cox and Saiegh, 2018; Hollyer, Rosendorff, and Vreeland, 2011; North and Weingast, 1989; Stasavage, 2003; Schultz and Weingast, 2003; Tomz and Wright, 2013). ${ }^{1}$

While democratic institutions may assuage investors' concerns regarding governments' willingness

\footnotetext{
${ }^{1}$ But also see Ballard-Rosa (2016); Ballard-Rosa, Mosley, and Wellhausen (2021).
} 
to pay, elections also affect sovereign risk assessments. When election outcomes are easy to predict, differences between candidates generate concerns about future government policies, especially if they portend partisan switches (Tomz, 2007; McGillivray and Smith, 2008). This is especially likely when partisan shifts are significant (Bernhard and Leblang, 2006; Vaaler, Schrage, and Block, 2006); when a country has recently undergone regime change (Frye, 2010); or when elected officials face few institutional constraints (Sattler, 2013). Especially where ideological differences are stark and political institutions are weak, investors worry that some left-leaning candidates will implement changes to investment policies, tax rates or public spending, or that left-leaning governments will be less committed to repayment (Campello, 2015). Consistent with a partisan business cycle process, elections that lead to a switch from a right- to a left-wing government often heighten risk assessments (Alesina and Sachs, 1988; Bernhard and Leblang, 2006; Block and Vaaler, 2004; Leblang, 2002; Vaaler, Schrage, and Block, 2006). Moreover, investors' risk perceptions also intensify when the outcome of the election is uncertain, as this widens the confidence intervals around investors' policy expectations (Freeman, Hays, and Stix, 2000; Frot and Santiso, 2013; Hays, Freeman, and Nesseth, 2003; Jensen and Schmith, 2005; Kelly, Pástor, and Veronesi, 2016; Waisman, Ye, and Zhu, 2015).

The "market responses to elections" literature, however, does not fully capture the process by which investors in developing country debt assess political risk. First, many analyses focus empirically on developed countries. But given greater diversity in economic policy outcomes and in political institutions, as well as governments' greater dependence on external finance, election dynamics should have a more pronounced effect in emerging and frontier markets. Second, these studies often do not specify the causal pathways through which elections affect investors' assessments. Rather, they tend to treat outcome uncertainty and policy uncertainty jointly. Third, these studies focus almost entirely on the level of sovereign risk premiums (that is, on the interest rates governments pay). In contrast, we expect that the more systematic effects of developing country elections will come in the form of volatility in risk premiums. Volatility results from uncertainty among investors regarding future policy, especially that of newly-elected left governments. When partisan labels have low informational content, investors are less able to reach consensus in risk pricing. Although volatility may have dramatic consequences for 
emerging economies, it has received significantly less attention from political economists.

\section{Ideological Shifts, Uncertainty and Volatility}

We begin by considering whether elections in developing countries generate systematic effects on bond premiums. One certainly could point to cases - Brazil's 2002 election is perhaps the best known - in which uncertainty in the pre-election period generates an increase in sovereign spreads. In that case, the increase in spreads likely stemmed from outcome uncertainty (the election was close, and investors had difficulty predicting who the winner would be) as well as from policy uncertainty (investors wondered how "left" Lula, a former union leader and leftist candidate, would act if he won office).

But our data suggest that the 2002 Brazilian election also is somewhat unusual. In Tables 1 and 2, we examine the effects of recent elections on developing countries' daily sovereign risk premiums (the country-specific bond yield against a U.S. Treasury of comparable maturity). The tables summarize an event study of 117 national elections ${ }^{2}$ in 47 developing countries, ${ }^{3}$ from 1995 to 2016 . Following Bernhard and Leblang (2006)'s design, we explore the occurrence of median abnormal returns in government bond markets.

For each election, we compare bond market outcomes in the ninety days prior to the election to the market's behavior during non-electoral ("normal”) periods. ${ }^{4}$ As Table 1 indicates, only $27 \%$ of elections are associated with significant market reactions. Abnormal changes are more likely when the election brings government change: $35 \%$ of elections with executive turnover are characterized by abnormal

\footnotetext{
${ }^{2}$ We include executive elections in presidential systems and general legislative elections in parliamentary systems in country-years with a Polity IV score equal to or greater than 5.

${ }^{3}$ These represent developing countries included in the EMBI Global index or for which CDS price data are available. The Supplementary Appendix lists these countries.

${ }^{4}$ To estimate normal behavior, we obtain an empirical distribution of median abnormal spread changes during a randomly-chosen, ninety-day period not within six months of an election. For each non-election window, we estimate a model of daily change in country risk spreads, accounting for various exogenous and systematic correlates of sovereign risk. The model residuals represent country-specific variation in daily sovereign spreads. We repeat this process 5000 times to obtain a distribution of abnormal spread changes during non-electoral periods and calculate a $90 \%$ confidence interval. We then compare the median abnormal change in non-electoral windows to that in the election window. Significant market reactions exist when the median electoral period change falls outside the $90 \%$ confidence interval. The Supplementary Appendix includes further details, as well as a similar analysis of CDS prices (credit default swaps - a derivative providing insurance against default).
} 
Table 1. Elections, executive turnover, and sovereign bond market reactions

\begin{tabular}{lccc}
\hline & All elections & $\begin{array}{c}\text { Elections with } \\
\text { executive turnover }\end{array}$ & $\begin{array}{c}\text { Elections without } \\
\text { executive turnover }\end{array}$ \\
\hline $\begin{array}{l}\text { Proportion of } \\
\text { elections with }\end{array}$ & $27 \%$ & $35 \%$ & $14 \%$ \\
$\begin{array}{l}\text { significant market } \\
\text { reaction }\end{array}$ & $(32 / 117)$ & $(26 / 75)$ & $(6 / 42)$ \\
\hline
\end{tabular}

Notes: Data on executive turnover are from V-Dem and the Database of Political Institutions.

Table 2. Elections, partisan outcomes, and sovereign bond market reactions

\begin{tabular}{|c|c|c|c|c|c|c|c|}
\hline & $\begin{array}{l}\text { All } \\
\text { elections }\end{array}$ & $\begin{array}{l}\text { Left } \\
\text { winner }\end{array}$ & $\begin{array}{l}\text { Right or } \\
\text { center } \\
\text { winner }\end{array}$ & $\begin{array}{l}\text { Any } \\
\text { partisan } \\
\text { switch }\end{array}$ & $\begin{array}{l}\text { Left-to- } \\
\text { right } \\
\text { switch }\end{array}$ & $\begin{array}{l}\text { Right-to- } \\
\text { left } \\
\text { switch }\end{array}$ & $\begin{array}{l}\text { Left } \\
\text { incumbent } \\
\text { winner (no } \\
\text { change) }\end{array}$ \\
\hline $\begin{array}{l}\text { Proportion of } \\
\text { elections with } \\
\text { significant market } \\
\text { reaction }\end{array}$ & $\begin{array}{c}27 \% \\
(32 / 117)\end{array}$ & $\begin{array}{c}28 \% \\
(10 / 36)\end{array}$ & $\begin{array}{c}47 \% \\
(14 / 30)\end{array}$ & $\begin{array}{c}47 \% \\
(9 / 19)\end{array}$ & $\begin{array}{l}43 \% \\
(3 / 7)\end{array}$ & $\begin{array}{l}50 \% \\
(6 / 12)\end{array}$ & $\begin{array}{c}24 \% \\
(7 / 29)\end{array}$ \\
\hline
\end{tabular}

Notes: See Table 1 notes.

returns, compared with $14 \%$ of elections without turnover. ${ }^{5}$ At the same time, of the 36 elections in which left governments emerge victorious, only $28 \%$ are marked by abnormal returns, as shown in Table 2. Indeed, abnormal returns are more prevalent when centrist or right-leaning candidates prevail ( $47 \%$ of elections), calling into question the "markets dislike left governments" claim.

Why might this be? Investors use various information shortcuts to make asset allocation decisions. Professional investors, who allocate capital across a broad array of assets and countries, tend to rely on heuristics (Calvo and Mendoza, 2000; Hafner-Burton et al., 2017; Mosley, 2003). Investors have access to large amounts of information; but they have short time horizons, diverse portfolios and a resulting incentive to economize where possible on the use of information. Government policies also

\footnotetext{
${ }^{5}$ We define turnover as a change in the chief executive, regardless of whether it also includes a shift in executive ideology.
} 
vary more among developing countries, relative to developed economies (Ahlquist, 2006), creating a further desire for heuristic devices. Investors' information shortcuts often include a country's category (“emerging” or "developed;" see Brooks, Cunha, and Mosley (2015)) as well as its economic partners (Gray, 2013; Gray and Hicks, 2014). Foreign investors also may take cues from domestic investors, who may be better able to gather and assess the accuracy of country-specific information (Cunha, 2017; Frot and Santiso, 2013).

Government partisanship also could serve as an information shortcut for investors. Indeed, in developed countries, left governments have been linked with lower sovereign credit ratings as well as higher risk premiums (Barta and Johnston, 2018; Mosley, 2003). But we do not expect government partisanship to serve as a reliable heuristic in developing countries, especially with respect to left-leaning governments. In developing countries, left-leaning political parties and candidates are a heterogeneous group. For instance (see Section 3.1), there is significantly more diversity in fiscal policy outcomes among left-leaning governments than among their right-leaning counterparts. While some left governments are fiscally profligate, others are disciplined. As result, partisan labels are not systematically informative: investors will not systematically shift the level of risk premiums in response to the election of left governments.

Rather, investors will experience significant uncertainty regarding the left governments' expected policy choices, especially when these governments are new to office. Investors' uncertainty may relate to who will be appointed to ministerial positions; what policies will be undertaken; and the effects of future policy changes on economic outcomes. When uncertainty is high, individual investors may interpret political events differently, especially when they vary in terms of information endowments, time horizons, and investment mandates. For example, Cunha (2017) finds that foreign and domestic investors process information about political events differently, creating the possibility of contagion from domestic to foreign investors (also see Borio and McCauley, 1996).

When uncertainty is high - as in the context of elections and partisan switches in developing countries - some investors may exit a country's markets. Or, they may hedge investment risks by purchasing derivatives, including options or credit default swaps (Arrow and Fisher, 1974; Borio and McCauley, 
1996; Pindyck, 1991). Other investors may remain, but assess risk differently, often taking opposing positions. Although heterogeneous expectations among investors provide the very fuel of normal market activity - for every seller of an asset there is a buyer with distinct expectations about its worth - this heterogeneity also can generate volatility (Xiong and Yan, 2010), especially when investors' confidence intervals widen. Uncertainty can generate a disjuncture between economic fundamentals and market movements (Borio and McCauley, 1996; Kelly, Pástor, and Veronesi, 2016; Pástor and Veronesi, 2013). And, central to our predictions, investors' uncertainty will result in greater volatility in sovereign bond markets.

It is worth noting that, while sovereign bond market volatility has received less attention from political scientists, other analyses have linked volatility in equity and currency markets to elections as well as government ideology. For example, Bernhard and Leblang (2006) treat stock market volatility as the result of uncertainty regarding cabinet formation in rich democracies (also see Białkowski, Gottschalk, and Wisniewski, 2008). Similarly, Jensen and Schmith (2005) treat stock market volatility in the runup to the 2002 election in Brazil as driven largely by uncertainty regarding the election outcome (rather than policy after the election). And Benton and Philips (2020)'s analysis of Donald Trump's Mexicorelated tweets treats these not as revealing new information about Trump's views toward Mexico, but as indicating Trump's level of commitment to specific actions (such as the renegotiation of NAFTA). As such, these communications can reduce investors' confidence in their capacity to predict future U.S. policy, increasing exchange rate volatility (also see Hays, Freeman, and Nesseth, 2003).

Volatility affects not only the financial sector, but also the real economy. Uncertainty over monetary, fiscal and regulatory policies, can have detrimental effects on economic activity (Baker, Bloom, and Davis, 2016; Kelly, Pástor, and Veronesi, 2016; Friedman, 1968; Rodrik, 1991; Hibbs, 1977; Hassett and Metcalf, 1999), by increasing the cost of finance (Gilchrist, Sim, and Zakrajšek, 2014) or delaying investment and hiring (Bernanke, 1983). While policy-induced volatility may be more common in developing economies, they also can occur in developed country asset markets, as they did after the 2008 global crisis (Berger, Dew-Becker, and Giglio, 2020; Barrero, Bloom, and Wright, 2017; Bachmann, Elstner, and Sims, 2013). Additionally, if government debt managers must refinance existing debt 
during heightened volatility, they may well incur higher-than-expected sovereign financing costs.

Our first empirical prediction is that electoral victories by left-leaning candidates and parties will generate higher variance in investors' risk assessments. Because left government partisanship is not a reliable information shortcut in the emerging markets context, investors will have varying assessments, or will frequently change their assessments, regarding future government policy, including the new government's willingness and ability to repay its debt obligations. This uncertainty among investors will generate greater volatility in sovereign spreads and CDS pricing, as investors rapidly change their views regarding the level of sovereign risk; or as some investors assume risk is high while others assume it is low. At the same time, we do not expect the level of sovereign bond spreads to move systematically response to an election (especially of a left-leaning government) or a partisan switch, all else equal.

\section{H1: In emerging market countries, the election of left governments is associated with greater} volatility in sovereign risk, all else being equal.

Second, we expect that investors' reactions to government partisanship will evolve over time. As newly-elected left governments reveal their policy preferences to investors through concrete actions such as cabinet appointments and fiscal and monetary policy choices, the effect of left government on market volatility will diminish. As such, volatility is less likely to occur as time since the election increases. Left governments reveal via policy whether they represent the "old left," advocating more heterodox and less investor-friendly policies, versus the "new left," favoring capital and trade liberalization, businessfriendly tax and regulatory policies, and sovereign debt repayment.

\section{$\mathrm{H} 2:$ The effect of left government on sovereign risk volatility is conditional on time in office. It} is highest when the government's time in office is lowest.

Our expectations regarding the conditioning effect of tenure in office apply only to left-leaning governments. Investors assume less diversity on economic policies among right-leaning parties and candidates and, therefore, are less inclined to hold varying views regarding expected government policies. $^{6}$. Moreover, the effect of time - which proxies for the arrival of more political information - on

\footnotetext{
${ }^{6}$ The recent rise of right-wing populist parties and governments may complicate this assumption for future analyses.
} 
investors' uncertainty also implies that elections that do not generate partisan changes to the left will have few systematic effects on volatility. Note as well that we are not arguing that governments necessarily become more adept over time at interacting with capital markets, or more inclined to pursue market-friendly policies (Shea and Solis, 2018). Rather, our claim is that investors become more confident and more unified in their ability to assess whether a given left government will prioritize domestic interests in default, for instance, over investors' desire for repayment (Ballard-Rosa, 2016).

Additionally, our expectations regarding volatility are consistent with analyses linking government turnover with financial market outcomes. McMenamin, Breen, and Muńoz-Portillo (2016) find that bond market reactions to OECD elections unfold over several weeks. While they take this as evidence against the efficient markets hypothesis, their findings also imply that elections generate uncertainty not only about outcomes, but also about policies. Indeed, they find that the degree of change in ideological composition of the government often predicts abnormal returns. Similarly, analyzing developing country equity markets, Frot and Santiso (2013) report that election-related leadership turnover reduces global fund managers' willingness to invest (also see Vaaler, Schrage, and Block, 2006). Fowler (2006) notes, in the context of US presidential elections, that increases in the probability of incumbency generate declines in interest rates.

\section{Empirical Analysis}

We begin our empirical analysis by examining evidence related to our assumption that, in developing countries, party labels provide limited information to sovereign debt investors. We compare the volatility of discretionary fiscal policy under left, center and right governments. We then test Hypotheses 1 and 2 using data on sovereign spreads and CDS pricing for a large sample of developing countries. We consider the effect of elections, government ideology, and time in office on the volatility of sovereign spreads, as well as on the level of spreads (the size of the country risk premium). 


\subsection{Government Partisanship and Fiscal Policy Uncertainty}

We argue that, in developing countries, government partisanship is too noisy to serve as a useful information shortcut for investors, especially for left parties and candidates. We assert that the wider heterogeneity of economic policies on the left - from the market-friendly policies of the moderate left to the radical interventionist policies of the populist left - creates considerable uncertainty. To confirm that this expectation is accurate, we compare the volatility of fiscal policy by government partisanship. We follow Fatás and Mihov (2013) in calculating fiscal policy volatility as the standard deviation of the residuals from a regression of government spending growth on GDP growth. The residuals of this regression capture fiscal policy over and above the business cycle, thus measuring governments' discretionary use of fiscal policy (see details in the Supplementary Appendix).

We calculate fiscal policy volatility under each leader for a set of 101 middle-income countries between 1980-2015. Table 3 displays the mean and standard deviation of fiscal policy volatility, by partisanship. On average, left governments exhibit higher policy volatility (a higher mean) than right and center governments. This suggests that left governments are associated with greater policy uncertainty. Moreover, left governments are more heterogeneous than right and center governments, as indicated by the larger standard deviation. These data support our claim that sovereign debt investors face higher uncertainty when elections bring new left-leaning parties to office compared to right or center parties.

Might these differences be driven instead by populism? It is possible that investors are more responsive to differences between populist and non-populist parties than to differences between left and right parties. Table 3 therefore further categorizes governments as populist or non-populist, using data from Kenny (Forthcoming). ${ }^{7}$ Left governments display greater fiscal policy volatility, on average, whether they are populist or non-populist. Non-populist right and center governments have similar policy volatility (though note that there is only one populist and centrist government in the dataset). Left governments are also more diverse, conditional on populist orientation, as evidenced by an overall

\footnotetext{
${ }^{7}$ Note that both the partisanship and the populism data end in 2015 , before the most recent wave of right-wing populism.
} 
Table 3. Fiscal policy volatility by government partisanship and populism

\begin{tabular}{|c|c|c|c|c|c|c|}
\hline & \multicolumn{2}{|l|}{ Left } & \multicolumn{2}{|c|}{ Right } & \multicolumn{2}{|c|}{ Center } \\
\hline Mean & \multicolumn{2}{|c|}{0.104} & \multicolumn{2}{|c|}{0.091} & \multicolumn{2}{|c|}{0.062} \\
\hline Std. Dev. & \multicolumn{2}{|c|}{0.136} & \multicolumn{2}{|c|}{0.117} & \multicolumn{2}{|c|}{0.047} \\
\hline \multirow[t]{2}{*}{$\mathrm{N}$} & 151 & & 118 & & 41 & \\
\hline & Non-populist & Populist & Non-populist & Populist & Non-populist & Populist \\
\hline Mean & 0.086 & 0.079 & 0.061 & 0.065 & 0.061 & 0.029 \\
\hline Std. Dev. & 0.067 & 0.053 & 0.063 & 0.043 & 0.047 & \\
\hline $\mathrm{N}$ & 84 & 6 & 65 & 5 & 25 & 1 \\
\hline
\end{tabular}

Notes: Data on partisanship from the Database of Political Institutions. Data on populism from Kenny (Forthcoming). The difference in the total number of cases in the top and bottom panels reflects the more limited coverage of the populism dataset.

larger standard deviation. These data therefore corroborate our assumption of greater heterogeneity and policy uncertainty under left governments.

\subsection{Partisanship, Time in Office, and Sovereign Risk}

Dependent variable. Next, we assess Hypotheses 1 and 2 using monthly data on sovereign bond premiums. We consider the effects of elections, government ideology and time in office on the volatility, as well as the levels, of sovereign spreads. We use two measures of sovereign risk: sovereign bond spreads and credit default swap (CDS) pricing. The sovereign bond spread is the difference between a government's bond yield and the yield on a risk-free asset (a US Treasury of comparable maturity). Our bond spread measure is taken from the J.P. Morgan Emerging Markets Bond Index Global (EMBI-G). To be included in the index, a government's debt instruments must have a minimum outstanding face value of US\$ 500 million. Given that the EMBI-G includes only dollar-denominated instruments, changes in its value mainly reflect considerations of default risk - as opposed to inflation and exchange rate risk.

While studies of developed country sovereign debt often use interest rates on a benchmark (tenyear maturity, domestic currency denominated) bond as the dependent variable, developing country governments often do not issue a benchmark instrument. The EMBI-G and other indices aggregates 
instruments with varying maturities, liquidity and repayment guarantees (i.e. Brady Bonds). The EMBI-G data includes 67 nations, all of which issue dollar-denominated Brady Bonds, Eurobonds, and trade bonds. This set of middle-income developing nations draws from Latin America, Asia, the Middle East, Central and Eastern Europe, and sub-Saharan Africa. While this does not include every developing country issuer of debt, the EMBI-G's requirement for secondary market trading liquidity is less than other indices (e.g. the EMBI+), allowing for broader coverage. The EMBI data spans January 1994 to December 2015, with individual country coverage varying according to when the country was added to EMBI-G. The launch of the EMBI indices coincides with the shift toward capital market openness, and toward portfolio market-based government financing, in the developing world.

Our second measure is the spread on credit default swap (CDS) contracts on external sovereign debt. CDS contracts provide insurance against sovereign default or restructuring. The purchaser of default protection pays a fee to the seller (the insurer). If the government defaults or restructures its debt durign the contract's term, the insurer compensates the buyer (Longstaff et al., 2011; Mengle, 2007). CDS insurers typically respond to new information more quickly than sovereign ratings agencies: they do not have a direct contractual relationship with the issuing government, which might make them hesistant to adjust ratings. CDS outcomes thus provide a real-time signal of market assessments of political risk (Coudert and Gex, 2013; Longstaff et al., 2011; Mosley, Paniagua, and Wibbels, 2020).

We obtain CDS prices from Bloomberg and Datastream, which collect market quotations from industry sources for CDS contracts on U.S. dollar-denominated sovereign issues. The universe of emerging-market sovereign CDS prices includes 36 countries. The CDS data span from November 2000 to December 2015; the dataset is unbalanced by country, reflecting different initial dates when CDS contracts became available for trading.

The list of countries and time periods included in the analysis appears in the Supplementary Appendix. Our statistical analyses model both the conditional mean and the variance of EMBI-G bond spreads and CDS spreads. Modeling the conditional mean addresses our expectations regarding the levels of risk premiums, while modeling the variance addresses our claims regarding investors' uncertainty around those premiums. Recall that we anticipate few systematic effects of government ideology 
on levels, while we expect a relationship (conditional on time in office) between left partisanship and volatility.

Main explanatory variables. We classify government partisanship using information from the Database of Political Institutions (DPI). Given that most countries in our sample are characterized by presidential (rather than parliamentary) systems, we focus on the ideological orientation of the chief executive, rather than that of the largest legislative party or the governing legislative coalition. Indeed, in most presidential systems, sovereign repayment is an executive, rather than legislative, decision (North and Weingast, 1989). For our main analyses, we generate a dichotomous measure, differentiating between left versus right and centrist government types. Because our analysis of fiscal policy volatility shows slight differences in right versus centrist governments, we also explore the distinct effects of left and right governments (relative to centrist ones).

We expect any effects of left government ideology to be moderated by time in office: new governments generate greater uncertainty for investors, which diminishes with time. For governments of all ideological stripes, time in office may facilitate more sophisticated interactions between investors and government dept managers (as implied by Shea and Solis (2018)), as well as more accurate investors assessments of governments' types. Hence, we expect a negative direct relationship between time in office and the volatility of country risk spreads. Additionally, we anticipate that time in office conditions the effect of left government. The excess spread volatility associated with newly-elected left governments should decline with time in office.

Our months-in-office variable counts the number of months since a government was first elected. We use presidential election dates in presidential systems and general legislative election dates in parliamentary systems. We use the DPI and V-Dem databases to identify election dates and government duration. To capture investors' incorporation of new information about sovereign risk, we count a government's time in office from the month in which the government was elected rather than from its assumption of office. Sovereign debt investors should update their assessments of default risk the moment the identity of the future government is revealed. ${ }^{8}$ Moreover, if partisan labels do have heuristic

\footnotetext{
${ }^{8}$ Because over two thirds of the countries in our sample have presidential, as opposed to parliamentary, systems, there is less concern about coalition formation processes in the post-election period.
} 
value for investors, their value should be highest when investors know the ideology of the government but have not yet observed any government actions - i.e., in the period between the election and the taking of office. We also include a multiplicative interaction between left government and time in office; we expect a negative coefficient on this interaction term.

To account for heightened market volatility induced by election outcome (versus policy) uncertainty (Hays, Freeman, and Nesseth, 2003; Jensen and Schmith, 2005; Freeman, Hays, and Stix, 2000), our models include an election period indicator. This dichotomous variable takes the value of one in the six months prior to and including the election month (for presidential elections in presidential systems and general legislative elections in parliamentary systems), and zero otherwise. As a robustness check, we further account for close elections, as they induce greater outcome uncertainty.

Empirical model. We assess the interaction of government ideology and time in office using a heteroskedastic regression model of country risk spreads. This allows us to explicitly model the spread volatility as a function of political and economic variables in the context of time-series cross-sectional data. The model is: $\Delta$ Country $\operatorname{Spread}_{i t} \sim N\left(\mu_{i t}, \sigma_{i t}^{2}\right)$, where the variance of the sovereign spread, $\sigma_{i t}^{2}$, is allowed to vary over time and across countries (Rigby and Stasinopoulos, 2005; Smyth, 1989). We thus take the realized volatility of the country spread to express market uncertainty. Financial volatility as captured by the variance of asset prices is a common market-based measure of uncertainty (Berger, Dew-Becker, and Giglio, 2020; Borio and McCauley, 1996; Leblang and Mukherjee, 2005; Leblang and Bernhard, 2006). A higher spread variance reflects bond investors' greater uncertainty about sovereign risk, while a lower variance indicates greater certainty regarding risk.

Our empirical strategy allows us to simultaneously model the conditional mean and conditional variance (volatility) of sovereign spreads, specifying both moments as a function of exogenous variables. We can observe how the interaction of government ideology and time in office, over and above conventional correlates of default risk, affects the volatility of the country spread. The monthly change in 
the country spread is modeled as:

$$
\begin{gathered}
\Delta \text { Country Spread }_{i t}=\beta_{1} \text { Left Government }_{i t}+\beta_{2} \text { Months in Office }_{i t}+\beta_{3} \text { (Left Government } \times \\
\text { Months in Office })_{i t}+\boldsymbol{X} \boldsymbol{\beta}+\alpha_{i}+\epsilon_{i t} \\
\ln \left(\sigma_{i t}\right)=\gamma_{0}+\gamma_{1} \text { Left Government }_{i t}+\gamma_{2} \text { Months in Office }_{i t}+\gamma_{3} \text { (Left Government } \times \\
\text { Months in Office })_{i t}+\boldsymbol{Z} \boldsymbol{\gamma}
\end{gathered}
$$

where the change in the spread and its volatility are both a function of our explanatory variables and several relevant controls. In the conditional volatility equation, $\ln \left(\sigma_{i t}\right)$ is the (logged) standard deviation of the monthly spread, and $\gamma_{k}$ are the main parameters of substantive interest to be estimated. They capture the sensitivity of the spread volatility to government partisanship and experience in office. $\boldsymbol{X}$ and $\boldsymbol{Z}$ are vectors of controls for the mean and volatility equations, respectively, that include indicators of the electoral cycle, sovereign creditworthiness, macroeconomic factors, and global economic conditions; $\alpha_{i}$ are country-specific intercepts (fixed effects); and $\epsilon_{i t}$ is an error term. The multiplicative interaction between left government and months in office captures the conditional relationship between sovereign spreads and government ideology, with time in office expected to moderating the effects of left partisanship on spread volatility.

We estimate the two equations simultaneously through maximum likelihood. We test for serial correlation using the Wooldridge test for AR(1) errors in fixed effects panel models, and include a lagged dependent variable where residual autocorrelation is detected. Standard errors are clustered at the country level to account for error correlation within countries.

We note that a common approach to modeling volatility is to use a generalized autoregressive conditional heteroskedasticity (GARCH) model, given its ability to account for persistence in volatility. Because GARCH models are unsuitable for panel data, we adopt the above approach instead, which allows us to exploit the time-series cross-sectional variation in our data, as well as to account for timeinvariant country-level factors by including country fixed effects. Nonetheless, we also report both pooled and country-specific GARCH estimates as robustness checks, showing that our conclusions 
remain the same.

Country-level macroeconomic controls. The controls included in the conditional mean equation capture governments' capacity to service outstanding debt. Typically, a country's current account balance, inflation rate, and stock of existing debt correlate with capacity to pay (Ballard-Rosa, Mosley, and Wellhausen, 2021; Tomz, 2007). We therefore control for the current account balance (scaled to GDP) and the monthly change in the consumer price index. Inflation, however, may be less important to holders of foreign-currency denominated assets than to investors in assets denominated in domestic currency. We also include an overall measure of external debt (scaled to GDP); this indicator is much more widely available than measures of debt composition (maturity, currency). The overall debt burden captures the extent to which a government must devote a larger share of their resources to debt service. Moreover, we control for the stock of outstanding short-term debt as a proportion of international reserves; when short-term debt is larger, governments are more vulnerable to adverse shocks in global capital markets (IMF, 2000). ${ }^{9}$

Additionally, we account for variation in capital account openness. While openness exposes sovereign borrowers to greater pressures from global markets (Brooks, 2004; Mosley, 2003), it also allows them to access a larger pool of funds (Simmons, 1999). And by allowing investors to easily remove their investments, capital account openness can signal credibility (Bartolini and Drazen, 1997). We expect the latter effect to dominate, so that nations with greater levels of openness should have lower and less volatile risk spreads. We use the Chinn-Ito index, which measures the extent of legal restrictions on cross-border financial transactions. Finally, we control for the growth rate of GDP. Where growth is higher, investors will be more optimistic in their assessments of sovereign risk. In our analyses, current account balance, external debt, short-term debt to reserves, GDP growth and capital account openness are measured annually, while country spreads are measured monthly. We linearly interpolate the monthly values when the right-hand side variable is sampled annually. While temporally-aggregated data tends to attenuate parameter estimates, it allows for broader coverage of emerging market coun-

\footnotetext{
${ }^{9}$ Government fiscal balances also may affect default risk: governments that run large and persistent deficits should be perceived as less creditworthy. The fiscal balance indicator, however, is available for a much more limited set of observations, so we do not include it.
} 
tries. We report alternative estimations using quarterly-sampled data on current account, debt, and GDP growth - with more limited country and temporal coverage - as a robustness check.

Global market conditions. Sovereign borrowers' access to debt also is affected by global capital market conditions (Kennedy and Palerm, 2014; Forbes and Warnock, 2012). Indeed, global conditions typically account for a large share of the over-time variation in country risk spreads (Longstaff et al., 2011; Campello, 2015; Ballard-Rosa, Mosley, and Wellhausen, 2021; Bauerle Danzman, Winecoff, and Oatley, 2017). Accordingly, we proxy for global liquidity by including the ten-year constant maturity U.S. Treasury yield. Given the role of the U.S. dollar as well as U.S. Treasury securities as benchmark assets, increases in U.S. rates are typically associated with declines in global liquidity and increased investor risk aversion (Eichengreen and Mody, 1998; Kennedy and Palerm, 2014). Moreover, U.S. interest rates may indicate shifts in the global business cycle, as well as flight-to-quality dynamics (Longstaff et al., 2011).

Because changes in equity markets also can affect pricing in bond markets, we include a measure of risk in global equity markets, the price-earnings ratio for the S\&P 500 index (Longstaff et al., 2011). As another measure of global market conditions, we include the VIX index, a forward-looking measure of global uncertainty based on the 30-day implied volatility generated from S\&P 500 options (also see Longstaff et al., 2011). This represents investors' view of short-term volatility in the U.S. market, capturing global uncertainty shocks and investor risk aversion (Forbes and Warnock, 2012). Furthermore, we include an index of energy commodity prices; high commodity prices increase the foreign currency revenues of primary exporters and boost their ability to service debt. As such, we might expect commodity prices also to affect investors' sovereign risk assessments. We also control for the global default rate on foreign-currency denominated bonds, which should be positively related to country-specific spreads. Finally, we take contagion- and peer country-related risk assessments into account using a regional diffusion term, calculated as the average sovereign spread of a country's regional neighbors (Brooks, Cunha, and Mosley, 2015).

The volatility equation includes global and country-level factors identified in previous analyses as affecting financial market volatility. The VIX index captures global uncertainty, so that our parameter 
estimates of interest reflect variation in the volatility of country spreads net of global sources of market uncertainty. We also include capital account openness, to capture a country's exposure to global volatility shocks.

\section{Results}

Table 4 presents the main results from the heteroskedastic cross-sectional time-series models of EMBI$\mathrm{G}$ and CDS spreads. We report results both for the conditional mean (level) and conditional variance (volatility) models. Models 1 and 5 show baseline specifications for EMBI-G and CDS spreads, respectively, in which left government and months in office enter additively. The remaining models include the multiplicative interaction between left government and time in office, representing the expected conditional relationship. Models 2 and 6 show baseline specifications with no additional controls, while models 3 and 7 report fully specified models of EMBI-G and CDS spreads, respectively. Finally, models 4 and 8 add a multiplicative interaction between right government and time in office to fully disaggregate the effects of left and right party labels.

With respect to the conditional mean - the level of sovereign spreads - Table 4 reports null results for the association between elections and risk premiums. While electoral uncertainty translates into higher volatility, it does not necessarily produce higher risk premiums. Moreover, we find no discernible effect of government ideology or time in office on the conditional mean. The coefficient estimates for left government and time in office (and their interaction) are statistically insignificant in all specifications, indicating that the uncertainty over debt repayment associated with left partisan labels operates largely through the spread volatility. Throughout multiple specifications and robust-

ness checks, we find no evidence of an effect of government ideology through the conditional mean of spread changes. Therefore, in the remaining discussion, we focus on our central results regarding the volatility of sovereign spreads.

The results for the variance equation demonstrate sovereign spreads are considerably more volatile under left governments. The effect of partisanship, however, is moderated by governments' time in 
office. Across all models of the variance equation in Table 4, we find consistent and robust evidence of a statistically significant interaction of left partisanship and time in office. The negative sign on the interaction term indicates that time in office mitigates the higher spread volatility associated with left governments. While investor uncertainty generates volatility early in left governments terms, this effect is typically softened by experience, as market participants become more able to form precise beliefs regarding sovereign risk.

Over time, spread volatility under left governments converges to that of right and centrist governments. Figure 1 shows the interplay of government ideology and time in office in our sample of emerging market countries. Left governments experience higher spread volatility on average, regardless of experience in office. But time in office substantially reduces this volatility. Right and centrist governments, by contrast, enjoy lower spread volatility throughout their terms, indicating that bond investors face less uncertainty regarding sovereign risk. Moreover, time in office has no discernible effect on volatility for right and center governments; they start from an already low baseline.

In models 4 and 8, we examine the possibility of heterogeneous effects for left and right governments by including interaction terms for each group (Left $\times$ Months in office; Right $\times$ Months in office), where center government is the baseline. The results for left governments remain virtually identical, while the results for right governments vary across models. We find a positive interaction in the EMBI-G sample and a negative interaction in the CDS sample. We are thus not able to substantiate unambiguous claims about right parties.

Overall, uncertainty over left governments' sovereign risk profile appears substantial. New left governments with little to no track record in economic policy elicit rapidly and widely changing risk assessments by market participants. But risk premium volatility is attenuated as left governments reveal their type via policy actions. As Figure 1 shows, the volatility (standard deviation) of the monthly change in the EMBI spread under a right or center government is just over 100 basis points - i.e., a typical monthly variation in bond yields of 1 percentage point), while the volatility under left governments is about 2.6 times higher at about 260 basis points - a typical monthly variation in bond yields of 2.6 percentage points. Therefore, a newly elected left government wishing to issue new debt or roll 
Table 4. Partisanship, time in office, and sovereign risk.

Heteroskedastic regression analysis of EMBI-G and CDS spreads.

\begin{tabular}{|c|c|c|c|c|c|c|c|c|}
\hline & \multicolumn{4}{|c|}{ EMBI-G Spread } & \multicolumn{4}{|c|}{ CDS Spread } \\
\hline & (1) & (2) & (3) & $(4)$ & (5) & (6) & $(7)$ & (8) \\
\hline \multicolumn{9}{|l|}{ Mean equation (DV: $\Delta$ Spread) } \\
\hline$\Delta$ Spread $_{t-1}$ & $\begin{array}{c}0.096^{* *} \\
(0.040)\end{array}$ & $\begin{array}{c}0.087^{* *} \\
(0.041)\end{array}$ & $\begin{array}{l}0.066^{*} \\
(0.040)\end{array}$ & $\begin{array}{l}0.066^{*} \\
(0.037)\end{array}$ & & & & \\
\hline Months in office & $\begin{array}{c}-0.014 \\
(0.023)\end{array}$ & $\begin{array}{c}-0.019 \\
(0.031)\end{array}$ & $\begin{array}{l}-0.055 \\
(0.042)\end{array}$ & $\begin{array}{l}-0.013 \\
(0.026)\end{array}$ & $\begin{array}{c}0.002 \\
(0.023)\end{array}$ & $\begin{array}{c}0.022 \\
(0.026)\end{array}$ & $\begin{array}{c}0.053^{* *} \\
(0.026)\end{array}$ & $\begin{array}{c}0.055^{* *} \\
(0.026)\end{array}$ \\
\hline Left government & $\begin{array}{l}-7.293 \\
(7.529)\end{array}$ & $\begin{array}{l}-8.907 \\
(8.182)\end{array}$ & $\begin{array}{l}-9.562 \\
(8.005)\end{array}$ & $\begin{array}{c}-9.038 \\
(10.145)\end{array}$ & $\begin{array}{c}8.398 \\
(8.989)\end{array}$ & $\begin{array}{c}13.078 \\
(15.649)\end{array}$ & $\begin{array}{c}3.272 \\
(2.663)\end{array}$ & $\begin{array}{c}3.498 \\
(2.660)\end{array}$ \\
\hline Left government $\times$ Months in office & & $\begin{array}{c}0.030 \\
(0.036)\end{array}$ & $\begin{array}{c}0.020 \\
(0.034)\end{array}$ & $\begin{array}{l}-0.014 \\
(0.026)\end{array}$ & & $\begin{array}{l}-0.039 \\
(0.039)\end{array}$ & $\begin{array}{c}0.007 \\
(0.039)\end{array}$ & $\begin{array}{c}0.003 \\
(0.040)\end{array}$ \\
\hline Right government & & & & $\begin{array}{l}6.024 \\
(4.621)\end{array}$ & & & & $\begin{array}{c}-5.738^{* * *} \\
(2.150)\end{array}$ \\
\hline Right government $\times$ Months in office & & & & $\begin{array}{l}-0.154 \\
(0.119)\end{array}$ & & & & $\begin{array}{c}0.051 \\
(0.035)\end{array}$ \\
\hline Pre-election window & & & $\begin{array}{l}-1.672 \\
(4.198)\end{array}$ & $\begin{array}{l}-2.814 \\
(4.819)\end{array}$ & & & $\begin{array}{c}1.791 \\
(3.800)\end{array}$ & $\begin{array}{c}0.705 \\
(3.683)\end{array}$ \\
\hline Current account & & & $\begin{array}{c}-0.845^{* * *} \\
(0.207)\end{array}$ & $\begin{array}{c}-0.786^{* * *} \\
(0.198)\end{array}$ & & & $\begin{array}{l}-0.096 \\
(0.125)\end{array}$ & $\begin{array}{c}0.023 \\
(0.143)\end{array}$ \\
\hline External debt & & & $\begin{array}{c}-0.255^{*} \\
(0.154)\end{array}$ & $\begin{array}{c}-0.297^{*} \\
(0.158)\end{array}$ & & & $\begin{array}{c}0.034 \\
(0.058)\end{array}$ & $\begin{array}{c}0.029 \\
(0.071)\end{array}$ \\
\hline Short-term debt/reserves & & & $\begin{array}{c}0.023 \\
(0.017)\end{array}$ & $\begin{array}{l}0.029^{*} \\
(0.016)\end{array}$ & & & $\begin{array}{c}0.001 \\
(0.006)\end{array}$ & $\begin{array}{c}0.001 \\
(0.007)\end{array}$ \\
\hline GDP growth & & & $\begin{array}{c}0.326 \\
(0.556)\end{array}$ & $\begin{array}{c}0.200 \\
(0.600)\end{array}$ & & & $\begin{array}{c}1.025^{* * *} \\
(0.298)\end{array}$ & $\begin{array}{c}0.959^{* * *} \\
(0.285)\end{array}$ \\
\hline$\Delta$ Inflation & & & $\begin{array}{c}0.035 \\
(0.074)\end{array}$ & $\begin{array}{c}0.029 \\
(0.077)\end{array}$ & & & $\begin{array}{c}3.317 \\
(2.250)\end{array}$ & $\begin{array}{l}3.586^{*} \\
(1.996)\end{array}$ \\
\hline
\end{tabular}


Table 4 (Continued from previous page).

\begin{tabular}{|c|c|c|c|c|c|c|c|c|}
\hline & \multicolumn{4}{|c|}{ EMBI-G Spread } & \multicolumn{4}{|c|}{ CDS Spread } \\
\hline & $(1)$ & $(2)$ & (3) & $(4)$ & $(5)$ & $(6)$ & (7) & (8) \\
\hline$\Delta$ Treasury yield & & & $\begin{array}{l}-9.386 \\
(6.796)\end{array}$ & $\begin{array}{l}-9.804 \\
(7.060)\end{array}$ & & & $\begin{array}{l}-0.816 \\
(5.717)\end{array}$ & $\begin{array}{c}0.213 \\
(4.697)\end{array}$ \\
\hline$\Delta \mathrm{VIX}$ & & & $\begin{array}{c}4.851^{* * *} \\
(0.998)\end{array}$ & $\begin{array}{c}4.781^{* * *} \\
(0.918)\end{array}$ & & & $\begin{array}{c}2.921^{* * *} \\
(0.449)\end{array}$ & $\begin{array}{c}2.961^{* * *} \\
(0.440)\end{array}$ \\
\hline$\Delta$ Commodity prices & & & $\begin{array}{c}-0.932^{* * *} \\
(0.359)\end{array}$ & $\begin{array}{c}-0.856^{* *} \\
(0.366)\end{array}$ & & & $\begin{array}{c}-0.380^{* * *} \\
(0.099)\end{array}$ & $\begin{array}{c}-0.397^{* * *} \\
(0.100)\end{array}$ \\
\hline$\Delta$ Equity premium & & & $\begin{array}{c}-0.748^{*} \\
(0.402)\end{array}$ & $\begin{array}{c}-0.585 \\
(0.391)\end{array}$ & & & $\begin{array}{c}-0.594^{* * *} \\
(0.116)\end{array}$ & $\begin{array}{c}-0.611^{* * *} \\
(0.122)\end{array}$ \\
\hline$\Delta$ Regional diffusion & & & $\begin{array}{c}0.028^{* * *} \\
(0.006)\end{array}$ & $\begin{array}{c}0.027^{* * *} \\
(0.005)\end{array}$ & & & $\begin{array}{c}0.011^{* *} \\
(0.005)\end{array}$ & $\begin{array}{c}0.011^{* * *} \\
(0.004)\end{array}$ \\
\hline Capital account openness & & & $\begin{array}{l}-1.038 \\
(3.183)\end{array}$ & $\begin{array}{c}-0.393 \\
(2.675)\end{array}$ & & & $\begin{array}{c}1.477 \\
(1.604)\end{array}$ & $\begin{array}{c}1.559 \\
(1.682)\end{array}$ \\
\hline Global default rate & & & $\begin{array}{c}-0.769^{* *} \\
(0.319)\end{array}$ & $\begin{array}{c}-0.624^{*} \\
(0.340)\end{array}$ & & & $\begin{array}{c}0.273 \\
(0.319)\end{array}$ & $\begin{array}{c}0.187 \\
(0.259)\end{array}$ \\
\hline
\end{tabular}

\begin{tabular}{|c|c|c|c|c|c|c|c|c|}
\hline Months in office & $\begin{array}{c}-0.001^{*} \\
(0.001)\end{array}$ & $\begin{array}{l}-0.001 \\
(0.001)\end{array}$ & $\begin{array}{l}-0.001 \\
(0.001)\end{array}$ & $\begin{array}{c}-0.002^{* * *} \\
(0.001)\end{array}$ & $\begin{array}{c}-0.004^{* * *} \\
(0.001)\end{array}$ & $\begin{array}{c}-0.004^{* * *} \\
(0.001)\end{array}$ & $\begin{array}{c}-0.003^{* * *} \\
(0.001)\end{array}$ & $\begin{array}{c}-0.003^{* * *} \\
(0.001)\end{array}$ \\
\hline Left government & $\begin{array}{c}0.219 \\
(0.232)\end{array}$ & $\begin{array}{c}0.391 \\
(0.241)\end{array}$ & $\begin{array}{c}0.885^{* * *} \\
(0.263)\end{array}$ & $\begin{array}{c}0.806^{* * *} \\
(0.299)\end{array}$ & $\begin{array}{c}0.216 \\
(0.376)\end{array}$ & $\begin{array}{c}0.365 \\
(0.429)\end{array}$ & $\begin{array}{c}0.600 \\
(0.387)\end{array}$ & $\begin{array}{c}0.586 \\
(0.387)\end{array}$ \\
\hline Left government $\times$ Months in office & & $\begin{array}{c}-0.003^{* * *} \\
(0.001)\end{array}$ & $\begin{array}{c}-0.005^{* * *} \\
(0.001)\end{array}$ & $\begin{array}{c}-0.003^{* * *} \\
(0.001)\end{array}$ & & $\begin{array}{c}-0.002^{*} \\
(0.001)\end{array}$ & $\begin{array}{c}-0.003^{* * *} \\
(0.001)\end{array}$ & $\begin{array}{c}-0.003^{* * *} \\
(0.001)\end{array}$ \\
\hline Right government & & & & $\begin{array}{l}-0.140 \\
(0.216)\end{array}$ & & & & $\begin{array}{c}0.252 \\
(0.254)\end{array}$ \\
\hline Right government $\times$ Months in office & & & & $\begin{array}{c}0.003^{* * *} \\
(0.001)\end{array}$ & & & & $\begin{array}{c}-0.013^{* * *} \\
(0.002)\end{array}$ \\
\hline Pre-election window & & & $0.462^{* * *}$ & $0.489^{* * *}$ & & & $0.492^{*}$ & $0.508^{* *}$ \\
\hline
\end{tabular}

Continued on next page... 
Table 4 (Continued from previous page).

\begin{tabular}{|c|c|c|c|c|c|c|c|c|}
\hline & \multicolumn{4}{|c|}{ EMBI-G Spread } & \multicolumn{4}{|c|}{ CDS Spread } \\
\hline & (1) & $(2)$ & (3) & $(4)$ & (5) & (6) & $(7)$ & (8) \\
\hline & & & $(0.153)$ & $(0.157)$ & & & $(0.262)$ & $(0.259)$ \\
\hline$\Delta \mathrm{VIX}$ & & & $\begin{array}{c}0.026^{* * *} \\
(0.006)\end{array}$ & $\begin{array}{c}0.028^{* * *} \\
(0.005)\end{array}$ & & & $\begin{array}{c}0.016^{* * *} \\
(0.005)\end{array}$ & $\begin{array}{c}0.016^{* * *} \\
(0.005)\end{array}$ \\
\hline Capital account openness & & & $\begin{array}{c}-0.263^{* * *} \\
(0.068)\end{array}$ & $\begin{array}{c}-0.266^{* * *} \\
(0.070)\end{array}$ & & & $\begin{array}{c}-0.545^{* * *} \\
(0.066)\end{array}$ & $\begin{array}{c}-0.552^{* * *} \\
(0.057)\end{array}$ \\
\hline Constant & $\begin{array}{c}4.958 \\
(0.146)\end{array}$ & $\begin{array}{c}4.902 \\
(0.139)\end{array}$ & $\begin{array}{c}4.666 \\
(0.142)\end{array}$ & $\begin{array}{c}4.746 \\
(0.132)\end{array}$ & $\begin{array}{c}5.205 \\
(0.296)\end{array}$ & $\begin{array}{c}5.175 \\
(0.298)\end{array}$ & $\begin{array}{c}4.365 \\
(0.173)\end{array}$ & $\begin{array}{c}4.369 \\
(0.180)\end{array}$ \\
\hline Observations & 8451 & 8451 & 6033 & 6033 & 4476 & 4476 & 2723 & 2723 \\
\hline Countries & 67 & 67 & 51 & 51 & 36 & 36 & 20 & 20 \\
\hline Country Fixed Effects & $\checkmark$ & $\checkmark$ & $\checkmark$ & $\checkmark$ & $\checkmark$ & $\checkmark$ & $\checkmark$ & $\checkmark$ \\
\hline AIC & 107510.8 & 107186.6 & 74993.4 & 74800.8 & 56577.4 & 56503.1 & 29332.3 & 30774.1 \\
\hline Wooldridge AR(1) Test $F$-Stat. & $\begin{array}{c}0.02 \\
(p=0.88)\end{array}$ & $\begin{array}{c}0.01 \\
(p=0.92)\end{array}$ & $\begin{array}{c}0.005 \\
(p=0.95)\end{array}$ & $\begin{array}{c}0.0003 \\
(p=0.99)\end{array}$ & $\begin{array}{c}0.27 \\
(p=0.60)\end{array}$ & $\begin{array}{c}0.06 \\
(p=0.81)\end{array}$ & $\begin{array}{c}0.02 \\
(p=0.90)\end{array}$ & $\begin{array}{c}0.01 \\
(p=0.91)\end{array}$ \\
\hline
\end{tabular}

Notes: Table shows maximum likelihood estimates for heteroskedastic regression models of EMBI-G and CDS sovereign spreads. Standard errors clustered by country in parentheses. The Wooldridge test for AR(1) errors in fixed-effects panel models under the null of no serial correlation is reported in the last row. ${ }^{*} p<0.10 ;{ }^{* *} p<0.05 ;{ }^{* * *} p<0.01$. 


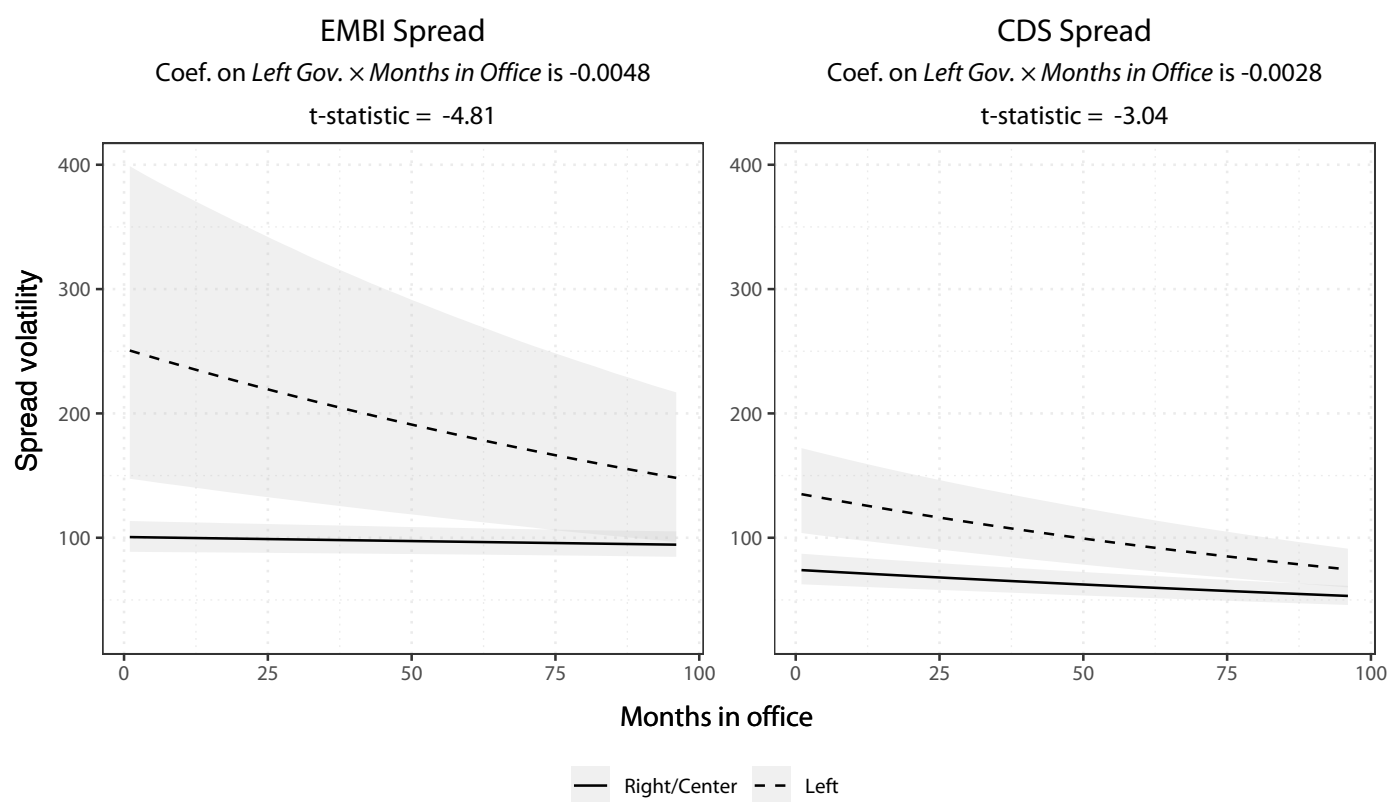

Figure 1. Predicted sovereign spread volatility under left and right/center governments. Volatility is the standard deviation of the EMBI or CDS spread in basis points. Predicted values obtained from models 3 and 6 in Table 4. Shaded areas are $95 \%$ confidence intervals.

over existing debt typically sees its potential borrowing costs fluctuate widely from month to month.

Results for the conditional variance equation in Table 4 also show that sovereign spreads become more volatile in the run-up to national elections. The coefficient on the election window dummy variable is positive and statistically significant for both EMBI-G and CDS spreads. This is consistent with the notion that the potential for political change heightens uncertainty over sovereign risk. Furthermore, the volatility of spreads increases with global risk aversion, as captured by the VIX. And capital account openness is associated with lower spread volatility, a result consistent with the claim that financial openness signals credibility.

We next consider whether global market conditions moderate the effect of partisanship on sovereign spread volatility. We expect that uncertainty about future government policies, especially those implemented by left-leaning governments, will be more pronounced when global liquidity is low. In such situations, proxied by high U.S. interest rates, investors are more risk averse. At the same time, time in office should have a greater mitigating effect under conditions of credit scarcity, as government-market interactions will serve an important role in allowing investors to better discriminate among government 
types.

Table 5 shows heteroskedastic regression models of EMBI-G and CDS spreads that interact left government and months in office with the 10-year constant maturity U.S. Treasury rate.

We find a negative and statistically significant coefficient on Left government $\times$ Months in office $\times$ Treasury rate, which indicates that in an environment of high interest rates (global credit scarcity), newly-elected left governments face significantly higher spread volatility. Moreover, in a risk average global environment, time in office has a greater role in reducing market uncertainty. Figure 2 demonstrates that the excess volatility under new left governments, relative to right and center governments, is much higher when interest rates are high. At the same time, experience in office brings steeper reductions in volatility for left governments. The results indicate that left governments in emerging-market economies are most prone to treatment based on partisan labels when global risk aversion is high, rendering investors more concerned with sovereign risk in developing countries (Ballard-Rosa, Mosley, and Wellhausen, 2021).

The case of Mexico's 2018 national election serves to illustrate the more general pattern revealed by our analyses. The campaign featured a contest among newcomers, including Andrés Manuel López Obrador (AMLO), a leftist, populist, and anti-establishment candidate from the MORENA party, founded in 2014. Some compared AMLO with Hugo Chávez, while others argued that AMLO's rhetoric - and his policies - would soften after the election. AMLO held a large lead in the polls throughout the campaign; he won 53 percent of votes, compared to 22 percent for his closest rival. As Figure 3 illustrates, sovereign bond markets reacted strongly to the campaign: the spread on Mexican debt (versus the overall EMBI+ index) generally increased between late January and the July 1 election. The volatility in spreads - the bottom panel - also was substantially greater before the election, relative to the second half of 2017. Certainly, other events - including campaign-related violence and turbulence in US-Mexico relations - contributed to these patterns.

With the polls strongly in AMLO's favor during the campaign, it is safe to assume that market movements prior to July 1, 2018 had little to do with outcome uncertainty. Rather, investors were experiencing significant uncertainty about how AMLO would govern once in office. Investors had 
Table 5. Global market conditions, partisanship, and sovereign spreads. Heteroskedastic regression analysis of EMBI and CDS spreads.

\begin{tabular}{|c|c|c|}
\hline $\begin{array}{l}\text { Variance equation } \\
\text { DV: Spread volatility } \ln (\sigma)\end{array}$ & $\begin{array}{l}\text { EMBI } \\
(1)\end{array}$ & $\begin{array}{c}\text { CDS } \\
(2)\end{array}$ \\
\hline Months in office $\times$ Left government $\times$ Treasury rate & $\begin{array}{c}-0.002^{* * *} \\
(0.0001)\end{array}$ & $\begin{array}{c}-0.001^{* * *} \\
(0.0001)\end{array}$ \\
\hline Months in office $\times$ Treasury rate & $\begin{array}{c}-0.001^{* * *} \\
(0.0001)\end{array}$ & $\begin{array}{c}-0.001^{* * *} \\
(0.0001)\end{array}$ \\
\hline Left government $\times$ Treasury rate & $\begin{array}{c}0.144 \\
(0.187)\end{array}$ & $\begin{array}{c}0.172 \\
(0.245)\end{array}$ \\
\hline Months in office $\times$ Left government & $\begin{array}{c}-0.0002 \\
(0.002)\end{array}$ & $\begin{array}{c}-0.00005 \\
(0.002)\end{array}$ \\
\hline Months in office & $\begin{array}{l}0.003^{* *} \\
(0.001)\end{array}$ & $\begin{array}{c}-0.002^{*} \\
(0.001)\end{array}$ \\
\hline Left government & $\begin{array}{c}0.417 \\
(0.783)\end{array}$ & $\begin{array}{l}-0.005 \\
(1.042)\end{array}$ \\
\hline Treasury rate & $\begin{array}{c}0.234^{* * *} \\
(0.086)\end{array}$ & $\begin{array}{l}-0.174 \\
(0.141)\end{array}$ \\
\hline Pre-election window & $\begin{array}{c}0.477^{* * *} \\
(0.151)\end{array}$ & $\begin{array}{c}0.619^{* * *} \\
(0.202)\end{array}$ \\
\hline$\Delta \mathrm{VIX}$ & $\begin{array}{c}0.021^{* * *} \\
(0.005)\end{array}$ & $\begin{array}{c}0.022^{* * *} \\
(0.006)\end{array}$ \\
\hline Capital account openness & $\begin{array}{c}-0.249^{* * *} \\
(0.071)\end{array}$ & $\begin{array}{c}-0.519^{* * *} \\
(0.064)\end{array}$ \\
\hline Constant & $\begin{array}{c}3.725 \\
(0.371)\end{array}$ & $\begin{array}{c}4.948 \\
(0.509)\end{array}$ \\
\hline Observations & 6042 & 2679 \\
\hline Countries & 51 & 20 \\
\hline Country Fixed Effects & $\checkmark$ & $\checkmark$ \\
\hline AIC & 107510.8 & 107186.6 \\
\hline Wooldridge AR(1) Test $F$-Stat. & $\begin{array}{c}2.57 \\
(p=0.11)\end{array}$ & $\begin{array}{c}0.07 \\
(p=0.79)\end{array}$ \\
\hline
\end{tabular}

Notes: Table shows maximum likelihood estimates for heteroskedastic regressions of EMBI and CDS spreads. For brevity, we only show estimates for the volatility component of the model; full results are reported in the Supplementary Appendix. Standard errors clustered by country in parentheses. The Wooldridge test for AR(1) errors in fixed-effects panel models under the null of no serial correlation is reported in the last row. ${ }^{*} p<0.10 ;{ }^{* *} p<0.05 ;{ }^{* * *} p<0.01$.

markedly different assessments of AMLO's expected policies: would his track record of strong leftist rhetoric, or his willingness to soften some of his more radical positions, prevail? Days before the elec- 


\section{EMBI Spread}

t-statistic on Left Gov. $\times$ Months in Office $\times$ Treasury Rate is -13.24

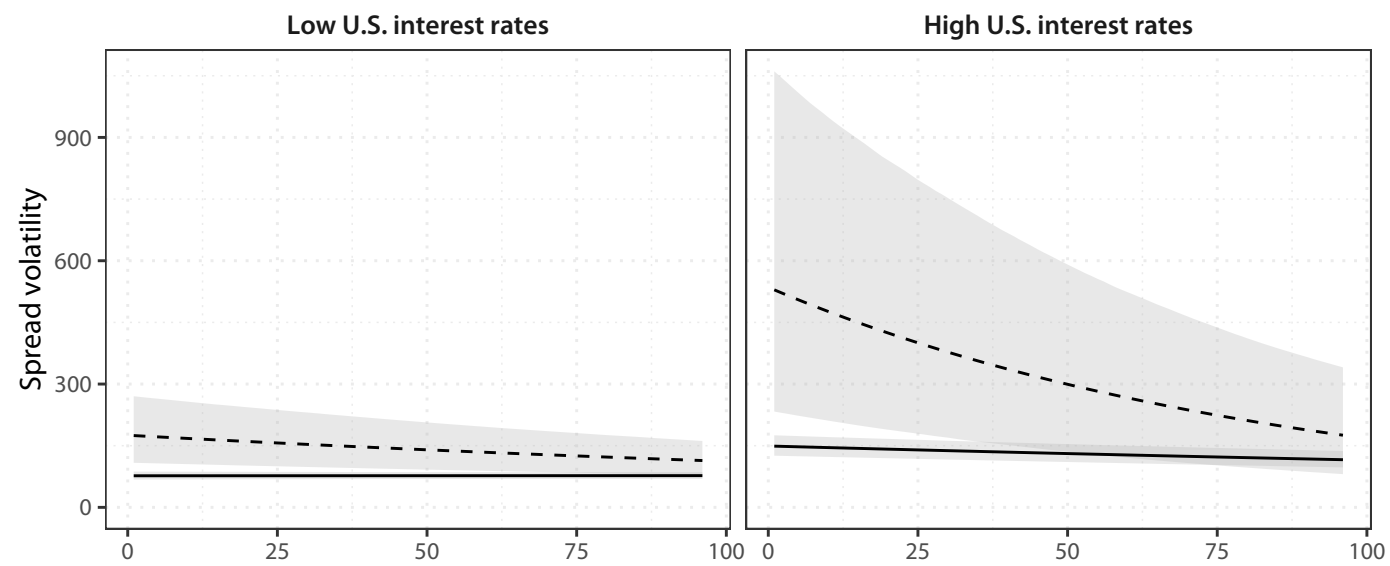

CDS Spread

t-statistic on Left Gov. $\times$ Months in Office $\times$ Treasury Rate is -7.54

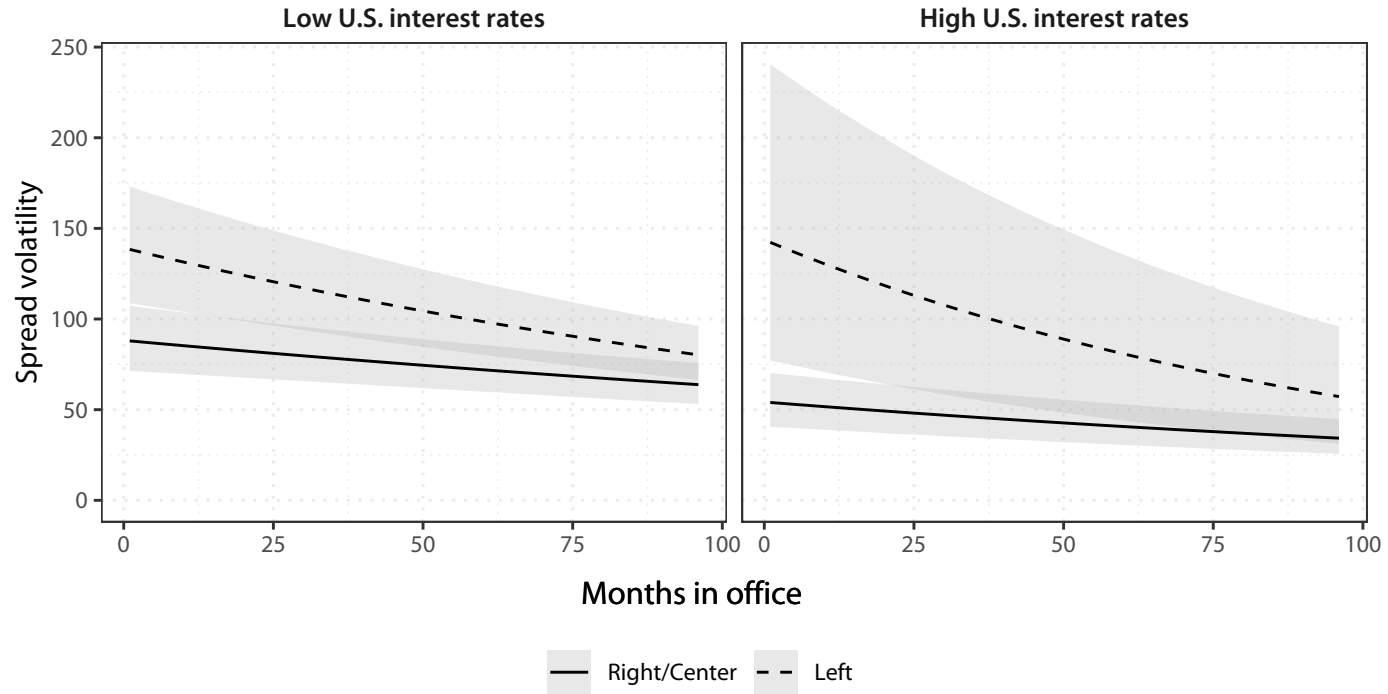

Figure 2. Conditioning effect of global liquidity (U.S. interest rates). Predicted sovereign spread volatility in low and high interest rate environments. Volatility is the standard deviation of the EMBI or CDS spread in basis points. U.S. interest rate is the ten-year constant maturity Treasury rate; low and high rates are the 25th and 75 th percentiles for the period under analysis, respectively. Shaded areas are $95 \%$ confidence intervals.

tion, for instance, Bloomberg News wondered whether AMLO sincerely hoped to work with private enterprises and investors, or whether he had "merely softened his edges in recent weeks in order to get elected." ${ }^{10}$ As investors took very different bets on the future of government policy, volatility increased

\footnotetext{
${ }^{10}$ https://www.bloomberg.com/view/articles/2018-06-29/mexico-election-has-global-market-implications
} 

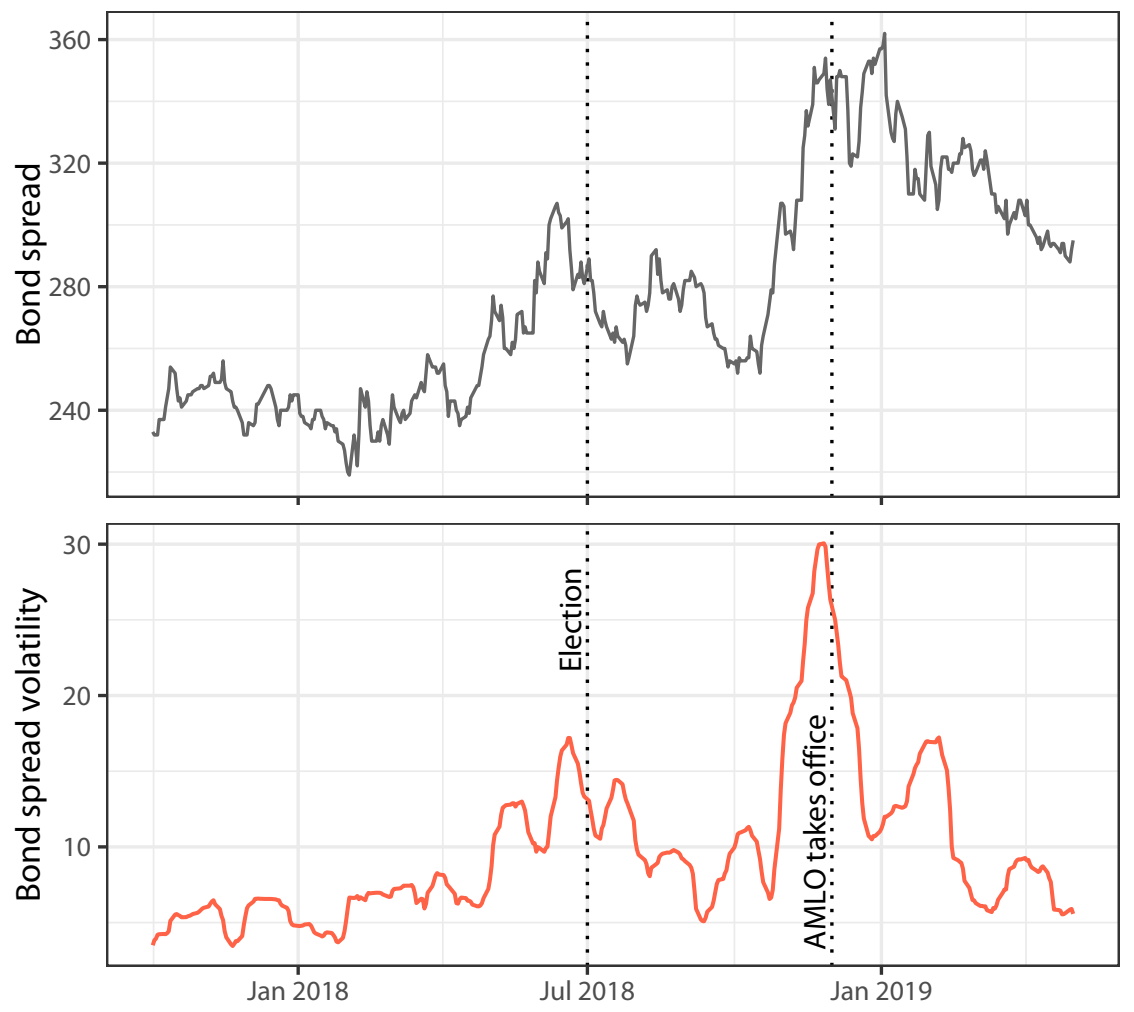

Figure 3. Sovereign debt markets and the 2018 Mexican presidential election. The top panel shows the daily EMBI+ spread for Mexican sovereign debt. The bottom panel shows the spread volatility as measured by the 30-day rolling standard deviation of the bond spread.

markedly; bond spreads (relative to risk-free assets) also widened ${ }^{11}$

The outcome of the election did not appear reassure investors; rather, volatility remains significant between July 1 and AMLO's December 1 inauguration, and it is particularly pronounced immediately before the inauguration. As the government take's office, and AMLO's policy actions provide better information about the president's type (low risk versus high risk left executive), volatility declines. Notably, bond spreads remain relatively high through AMLO's first six months in office, suggesting less that investors were reassured by the content of his actions, and - as our theory predicts - more that investors became more confident in their ability to assess AMLO's true type.

\footnotetext{
${ }^{11}$ While we do not find a systematic relationship in our statistical analyses between bond spreads and left governments, the Mexico 2018 case features not only increased volatility as a left government wins and then begins its term in office, but also increased spreads.
} 


\section{Additional Analyses and Robustness Checks}

Our results are robust to a host of alternative specifications, all reported in the Supplementary Appendix. All additional variables and controls described below are included both in the mean and volatility equations of each model. First, we consider whether populism confounds the effect of partisanship. Our analysis of fiscal policy volatility found that left populist governments show higher levels of policy heterogeneity. We test the possible effect of populism by including the interaction Left Government $\times$ Populist $\times$ Months in Office. In the sample of EMBI spreads, left populist governments experience significantly higher volatility than right populist governments. And in line with our findings above, spread volatility under left populist governments steeply declines with time in office. The difference in volatility between non-populist left and right governments, by contrast, is small, which indicates that high policy uncertainty under left populist governments is an important driver of bond market volatility. In contrast, we do not find significant differences between populist and non-populist governments in CDS markets; rather, partisanship remains the main source of uncertainty. These results generally are consistent with the claim that markets are more uncertain about left versus right governments, and that the difference is largely explained by wide variance in macroeconomic policy among left governments.

Our results are stronger for the subsample of established democracies. We use different criteria for selecting democratic observations: whether a country-month-year observation has a Polity score of at least 6 (on a -10 to 10 scale); whether a country has a Polity score of at least 6 during at least $75 \%$ of the sampled period; whether a country has an average Polity score of at least 6 in the sampled period; and whether a country maintains a minimum Polity score of at least 6 during the entire period. Because our argument presupposes some degree of electoral competition, we expect the interaction of partisanship and time in office to hold only in countries with relatively free elections. As expected, coefficients for the Left Government $\times$ Months in Office interaction are larger (in absolute value) and statistically significant for democracies in most estimations, while we find little evidence of that relationship in non-democracies.

There is reason to expect Latin America to be influential in our results. The region features prominently among issuers of sovereign bonds: in 2019, Latin America accounted for 34 percent of outstand- 


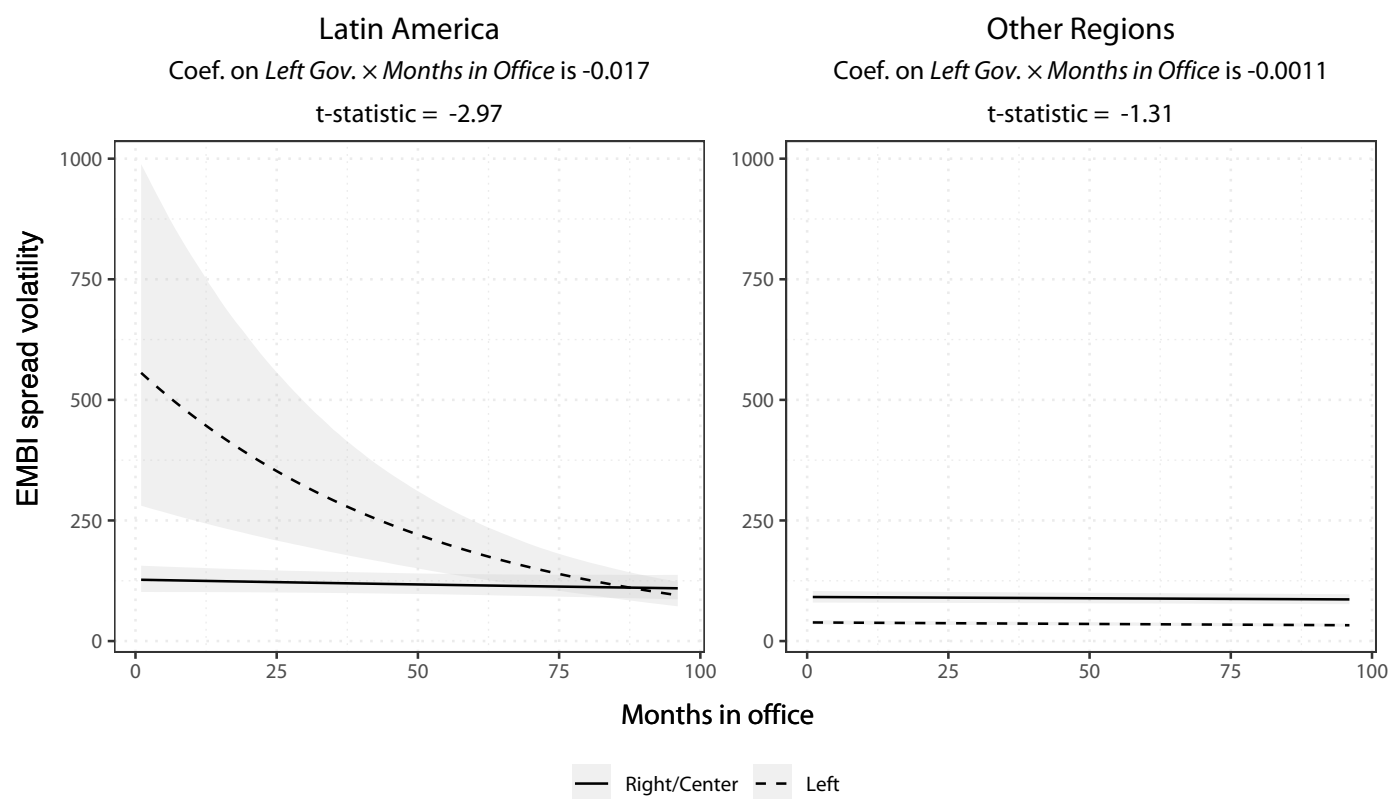

Figure 4. Predicted EMBI spread volatility under left and right/center governments in Latin America and elsewhere. Volatility is the standard deviation of the EMBI-G spread in basis points. Shaded areas are 95\% confidence intervals.

ing developing country and emerging market debt, a larger share than any other geographic region. ${ }^{12}$ The region accounts for $28 \%$ of our sample observations, followed by Eastern Europe (25\%), Asia (17\%), North Africa and the Middle East (13\%), and Sub-Saharan Africa (12\%). Additionally, Latin American sovereign bond stocks often are large, making issuers eligible for inclusion in the EMBI indexes and facilitating the creation of CDS instruments.

Furthermore, Latin America has a higher proportion of democratic observations than other regions in our sample, and party systems with clearly defined left and right programmatic parties are more common in the region. We thus perform separate analyses by region to assess heterogeneity. As expected, the interaction of partisanship and time in office in the volatility component of our model is substantively stronger and statistically significant for Latin America, whereas coefficients for other regions are smaller and statistically insignificant. Figure 4 summarizes this finding, comparing the effect of partisanship on spread volatility in Latin America vs. other regions.

${ }^{12}$ See Bank for International Settlements data on international debt securities,
https://stats.bis.org/statx/srs/table/cl?f=pdf.


Given these findings, we use Baker and Greene (2011)'s party ideology scores as an alternative measure of government ideology, which was developed specifically for Latin American party systems. This allows for more accurate comparisons within the Latin American subsample. The results are consistent with our main findings: estimates for the interaction of left government and time in office are negative and statistically significant in the volatility equation. New left governments in Latin America induce higher volatility, but time in office reduces this effect.

We account for close elections, defined as those with a margin of victory of 5 percentage points or less (and, alternatively, of 10 percentage points or less), as they induce greater outcome uncertainty. We find mixed evidence that close elections are associated with higher spread volatility, and no evidence that they affect the mean sovereign spread. In these models, the main results for the interaction of partisanship and time in office remain unchanged. We also consider the possibility that volatility might be driven by party turnover as opposed to leader turnover. When we interact the left government variable with the number of months a party has been in office, the results are nearly identical.

Our main results are robust to the inclusion of various measures of domestic institutional arrangements. These include regime type, to account for a possible "democratic advantage" (Beaulieu, Cox, and Saiegh, 2012; North and Weingast, 1989; Schultz and Weingast, 2003); executive constraints, as government ideology may matter less when individual leaders face stronger limits (Saiegh, 2009; Cox and Saiegh, 2018; Henisz, 2000); and central bank independence, which may reduce concerns about inflation risk (Bodea and Hicks, 2015, 2018; Johnson, 2016; Maxfield, 1997). The inclusion of controls for liberal democracy (V-Dem), political constraints (Henisz, 2000), and central bank independence (Bodea and Hicks, 2015) does not alter our key results.

In our sample, 44 of 52 countries (85 percent of country-months) have presidential systems. Our main results hold when we estimate models which include only country-months with presidential systems; not surprisingly, given the much smaller sample size, we do not find a statistically significant effect of ideology on volatility when we include only parliamentary system country-months.

We test numerous other specifications. We control for episodes of sovereign default, currency crises, and debt restructurings; exchange rate movements; and sovereign credit ratings. We employ 
alternative measures of capital account openness; and month-year fixed effects. We test for temporal structural breaks in our estimates using the 2007-08 Global Financial Crisis as a breakpoint. We also use alternative, quarterly IMF data for our macroeconomic controls (current account balance, external debt, and GDP growth).

Finally, we account for potential persistence in volatility within a GARCH framework. Volatility clustering over time is a common phenomenon in financial data and may affect inferences if not taken into account. We address this issue in the following ways. First, we use a pooled panel GARCH model, which allows us to model the autoregressive process in the volatility equation while also exploiting both cross-country and over-time variation. Second, we estimate a pooled panel GARCH-in-mean (GARCH-M) model that incorporates the spread volatility into the mean equation, which captures investors' demand for a higher risk premium during periods of high volatility. In both models, we find evidence of persistent volatility; importantly, our conclusions regarding the interaction of partisanship

and time in office remain unchanged. Finally, to assess the extent to which our conclusions might be driven by cross-sectional variation in volatility as opposed to over-time variation within countries, we estimate separate GARCH models for individual countries. For those countries with sufficiently long time series for GARCH estimation, we find that all statistically significant interactions between left government and time in office are in the expected direction.

\section{Conclusion}

Political economists have long been interested in how the ideological composition of governments affects the capacity of developing countries to access capital markets. Many emerging market governments worry about rolling over existing and financing new debt, especially during periods of electoral competition and partisan change. And many analysts have assumed that government partisanship is a useful information shortcut for internationally-diversified investors (Mosley, 2003), who associate left governments with heightened sovereign risk. A systematic negative market reaction to left governments would suggest that left-leaning parties and candidates might have strong incentives to shift 
toward market-friendly policies, perhaps at the expense of their domestic supporters' interests. Beyond the questions of democratic accountability that such dynamics raise, the welfare costs of volatility can reverberate throughout the macroeconomy as reduced government investment and counter-cyclical spending imperil private consumption, and growth.

Our theory and empirical analyses suggest, however, that the connection between government ideology and sovereign risk in emerging markets is much more nuanced than left-versus-right. There certainly are situations in which investors react negatively - with higher risk premiums - to strong campaign performance and electoral victories by left-leaning candidates and political parties. But there are many other situations in which sovereign bond investors do not charge higher risk premiums to leftleaning governments. The lack of a systematic relationship stems from the heterogeneity among left parties in developing countries: as a result of this variation, "left" is not a useful information shortcut for investors.

Rather, investors often are uncertain about how left-leaning parties and presidents in developing countries will act, with respect to economic policy. This uncertainty means that, early in left governments' terms, bond market outcomes exhibit excess volatility. Over time, as government actions provide more information, market volatility dissipates. Hence, left partisanship does matter to developing country sovereign debt markets, but it affects volatility rather than levels of risk premiums. Moreover, the effect of left partisanship diminishes as governments spend time in office. While political economists have tended to focus on levels, rather than on volatility, the latter can significantly affect sovereigns. Volatility renders government debt management - especially the rolling over of existing debt - much more challenging. Volatility also may affect the broader real economy, reducing agents' willingness to invest in the private sector.

Our findings contribute to efforts to understand outcomes in international political economy through the lens of micro-level behavioral analyses (Hafner-Burton et al., 2017). Future research could investigate further the ways in which political events other than elections - for instance, finance minister or central bank appointments, or debt restructurings - also affect investors' risk assessments. Additionally, different types of investors may have varying access to, and reactions to, political information. 
While we treat professional investors as a largely unified group, future scholarship could consider how different types of investors (even within the same asset market) respond differently to similar political phenomena.

Finally, researchers could devote greater attention to the ways in which government debt managers actively seek to structure interactions with private investors. In anticipation of tumultuous election campaigns, for instance, debt managers might arrange their borrowing to minimize the need to rollover debt during low "time in office" periods. While not all developing countries have the autonomy visà-vis markets to insulate themselves from political events, many do; and political economists would do well to pay greater attention to the agency of debtors in sovereign markets. Finally, scholars could investigate how the recent rise of populist political parties - left as well as right-leaning - in many parts of the developed and developing world may affect investors' assessments of political risk. 


\section{References}

Ahlquist, John S. 2006. "Economic Policy, Institutions, and Capital Flows: Portfolio and Direct Investment Flows in Developing Countries." International Studies Quarterly 50(3): 681-704.

Alesina, Alberto, and Jeffrey Sachs. 1988. "Political Parties and the Business Cycle in the United States, 19481984." Journal of Money, Credit and Banking 20(1): 63-82.

Archer, Candace C., Glen Biglaiser, and Karl DeRouen. 2007. "Sovereign Bonds and the "Democratic Advantage": Does Regime Type Affect Credit Rating Agency Ratings in the Developing World?" International Organization 61(2): 341-365.

Arrow, Kenneth J., and Anthony C. Fisher. 1974. "Environmental Preservation, Uncertainty, and Irreversibility." The Quarterly Journal of Economics 88(2): 312-319.

Bachmann, Rüdiger, Steffen Elstner, and Eric R. Sims. 2013. "Uncertainty and Economic Activity: Evidence from Business Survey Data." American Economic Journal: Macroeconomics 5(2): 217-249.

Baker, Andy, and Kenneth F. Greene. 2011. "The Latin American Left's Mandate: Free-Market Policies and Issue Voting in New Democracies.” World Politics 63(1): 43-77.

Baker, Scott R., Nicholas Bloom, and Steven J. Davis. 2016. "Measuring Economic Policy Uncertainty." The Quarterly Journal of Economics 131(4): 1593-1636.

Ballard-Rosa, Cameron. 2016. "Hungry for Change: Urban Bias and Autocratic Sovereign Default." International Organization 70(2): 313-346.

Ballard-Rosa, Cameron, Layna Mosley, and Rachel L. Wellhausen. 2021. "Contingent Advantage? Sovereign Borrowing, Democratic Institutions and Global Capital Cycles.” British Journal of Political Science 51(1): 353373.

Barrero, Jose Maria, Nicholas Bloom, and Ian Wright. 2017. “Short and Long Run Uncertainty.” NBER Working Paper 23676(August).

Barta, Zsófia, and Alison Johnston. 2018. "Rating Politics? Partisan Discrimination in Credit Ratings in Developed Economies." Comparative Political Studies 51(5): 587-620.

Bartolini, Leonardo, and Allan Drazen. 1997. “Capital-Account Liberalization as a Signal.” The American Economic Review 87(March): 138-154.

Bauerle Danzman, Sarah, W. Kindred Winecoff, and Thomas Oatley. 2017. "All Crises Are Global: Capital Cycles in an Imbalanced International Political Economy." International Studies Quarterly 61(4): 907-923.

Beaulieu, Emily, Gary W. Cox, and Sebastian Saiegh. 2012. "Sovereign Debt and Regime Type: Reconsidering the Democratic Advantage." International Organization 66(4): 709-738.

Benton, Allyson L., and Andrew Q. Philips. 2020. "Does the @realDonaldTrump Really Matter to Financial Markets?” American Journal of Political Science 64(1): 169-190.

Berger, David, Ian Dew-Becker, and Stefano Giglio. 2020. "Uncertainty Shocks as Second-Moment News Shocks." The Review of Economic Studies 87(1): 40-76. 
Bernanke, Ben S. 1983. "Irreversibility, Uncertainty, and Cyclical Investment." The Quarterly Journal of Economics 98(1): 85-106.

Bernhard, William, and David Leblang. 2006. "Polls and Pounds: Public Opinion and Exchange Rate Behavior in Britain." Quarterly Journal of Political Science 1(1): 25-47.

Białkowski, Jędrzej, Katrin Gottschalk, and Tomasz Piotr Wisniewski. 2008. "Stock Market Volatility around National Elections." Journal of Banking \& Finance 32(9): 1941-1953.

Biglaiser, Glen, and Joseph L. Staats. 2012. "Finding the "Democratic Advantage" in Sovereign Bond Ratings: The Importance of Strong Courts, Property Rights Protection, and the Rule of Law." International Organization 66(3): 515-535.

Block, Steven A., and Paul M. Vaaler. 2004. "The Price of Democracy: Sovereign Risk Ratings, Bond Spreads and Political Business Cycles in Developing Countries." Journal of International Money and Finance 23(6): 917-946.

Bodea, Cristina, and Raymond Hicks. 2015. "International Finance and Central Bank Independence: Institutional Diffusion and the Flow and Cost of Capital." The Journal of Politics 77(1): 268-284.

Bodea, Cristina, and Raymond Hicks. 2018. "Sovereign Credit Ratings and Central Banks: Why Do Analysts Pay Attention to Institutions?” Economics \& Politics 30(3): 340-365.

Borio, Claudio E.V., and Robert N. McCauley. 1996. "The Economics of Recent Bond Yield Volatility." BIS Economic Papers No. 45(July).

Brooks, Sarah M. 2004. "Explaining Capital Account Liberalization in Latin America: A Transitional Cost Approach.” World Politics 56(03): 389-430.

Brooks, Sarah M., Raphael Cunha, and Layna Mosley. 2015. "Categories, Creditworthiness, and Contagion: How Investors' Shortcuts Affect Sovereign Debt Markets.” International Studies Quarterly 59(3): 587-601.

Brooks, Sarah M., Raphael Cunha, and Layna Mosley. 2021. "Replication Data for Sovereign Risk and Government Change: Elections, Ideology and Experience. DOI: 10.7910/DVN/WJGJQ7.”.

Broz, J. Lawrence. 2013. "Partisan Financial Cycles." In Politics in the New Hard Times: The Great Recession in Comparative Perspective, ed. David A. Lake, and Miles Kahler. Ithaca, NY: Cornell University Press.

Calvo, Guillermo A., and Enrique G. Mendoza. 2000. "Capital-Markets Crises and Economic Collapse in Emerging Markets: An Informational-Frictions Approach.” The American Economic Review 90(2): 59-64.

Campello, Daniela. 2015. The Politics of Market Discipline in Latin America: Globalization and Democracy. New York, NY: Cambridge University Press.

Copelovitch, Mark, Christopher Gandrud, and Mark Hallerberg. 2018. "Financial Data Transparency, International Institutions, and Sovereign Borrowing Costs." International Studies Quarterly 62(1): 23-41.

Coudert, Virginie, and Mathieu Gex. 2013. "The Interactions between the Credit Default Swap and the Bond Markets in Financial Turmoil." Review of International Economics 21(3): 492-505.

Cox, Gary W., and Sebastian M. Saiegh. 2018. "Executive Constraint and Sovereign Debt: Quasi-Experimental Evidence From Argentina During the Baring Crisis." Comparative Political Studies p. 0010414018774363. 
Cunha, Raphael. 2017. Financial Globalization and Democracy: Foreign Capital, Domestic Capital, and Political Uncertainty in the Emerging World. Ph.D. Dissertation, The Ohio State University.

Eaton, Jonathan, and Mark Gersovitz. 1981. "Debt with Potential Repudiation: Theoretical and Empirical Analysis." The Review of Economic Studies 48(April): 289-309.

Eichengreen, Barry, and Ashoka Mody. 1998. What Explains Changing Spreads on Emerging-Market Debt: Fundamentals or Market Sentiment? Technical Report 6408 National Bureau of Economic Research Cambridge, MA: .

Eichengreen, Barry, and Ricardo Hausmann, eds. 2005. Other People's Money: Debt Denomination and Financial Instability in Emerging Market Economies. Chicago: University of Chicago Press.

Eichengreen, Barry, Andrew K. Rose, Charles Wyplosz, Bernard Dumas, and Axel Weber. 1995. "Exchange Market Mayhem: The Antecedents and Aftermath of Speculative Attacks." Economic Policy 10(October): 249312.

Fatás, Antonio, and Ilian Mihov. 2013. "Policy Volatility, Institutions, and Economic Growth." Review of Economics and Statistics 95(2): 362-376.

Forbes, Kristin J., and Francis E. Warnock. 2012. Debt- and Equity-Led Capital Flow Episodes. Working Paper 18329 National Bureau of Economic Research.

Fowler, James H. 2006. "Elections and Markets: The Effect of Partisanship, Policy Risk, and Electoral Margins on the Economy." Journal of Politics 68(1): 89-103.

Freeman, John R., Jude C. Hays, and Helmut Stix. 2000. "Democracy and Markets: The Case of Exchange Rates." American Journal of Political Science 44(3): 449-468.

Friedman, Milton. 1968. “The Role of Monetary Policy.” The American Economic Review 58(1): 1-17.

Frot, Emmanuel, and Javier Santiso. 2013. "Political Uncertainty and Portfolio Managers in Emerging Economies." Review of International Political Economy 20(1): 26-51.

Frye, Timothy. 2010. Building States and Markets After Communism: The Perils of Polarized Democracy. Cambridge University Press.

Gilchrist, Simon, Jae W. Sim, and Egon Zakrajšek. 2014. "Uncertainty, Financial Frictions, and Investment Dynamics." NBER Working Paper 20038.

Gray, Julia. 2013. The Company States Keep: International Economic Organizations and Investor Perceptions. Cambridge: Cambridge University Press.

Gray, Julia, and Raymond P. Hicks. 2014. "Reputations, Perceptions, and International Economic Agreements." International Interactions 40(3): 325-349.

Hafner-Burton, Emilie M., Stephan Haggard, David A. Lake, and David G. Victor. 2017. "The Behavioral Revolution and International Relations.” International Organization 71(S1): S1-S31.

Hassett, Kevin A., and Gilbert E. Metcalf. 1999. "Investment with Uncertain Tax Policy: Does Random Tax Policy Discourage Investment." The Economic Journal 109(457): 372-393. 
Hays, Jude C., John R. Freeman, and Hans Nesseth. 2003. "Exchange Rate Volatility and Democratization in Emerging Market Countries." International Studies Quarterly 47(2): 203-228.

Henisz, Witold J. 2000. “The Institutional Environment for Economic Growth.” Economics \& Politics 12(1): $1-31$.

Hibbs, Douglas A. 1977. "Political Parties and Macroeconomic Policy." The American Political Science Review 71(4): 1467-1487.

Hollyer, James R., B. Peter Rosendorff, and James Raymond Vreeland. 2011. "Democracy and Transparency." The Journal of Politics 73(4): 1191-1205.

IMF. 2000. Debt- and Reserve-Related Indicators of External Vulnerability. Technical report.

Jensen, Nathan M., and Scott Schmith. 2005. "Market Responses to Politics: The Rise of Lula and the Decline of the Brazilian Stock Market." Comparative Political Studies 38(10): 1245-1270.

Johnson, Juliet. 2016. Priests of Prosperity: How Central Bankers Transformed the Postcommunist World. Cornell University Press.

Kelly, Bryan, Lubos Pástor, and Pietro Veronesi. 2016. "The Price of Political Uncertainty: Theory and Evidence from the Option Market." The Journal of Finance 71(5): 2417-2480.

Kennedy, Mike, and Angel Palerm. 2014. "Emerging Market Bond Spreads: The Role of Global and Domestic Factors from 2002 to 2011." Journal of International Money and Finance 43: 70-87.

Kenny, Paul D. Forthcoming. ““The Enemy of the People”: Populists and Press Freedom.” Political Research Quarterly.

Leblang, David A. 2002. “The Political Economy of Speculative Attacks in the Developing World.” International Studies Quarterly 46(1): 69-91.

Leblang, David, and Bumba Mukherjee. 2005. "Government Partisanship, Elections, and the Stock Market: Examining American and British Stock Returns, 1930-2000.” American Journal of Political Science 49(4): 780-802.

Leblang, David, and William Bernhard. 2006. "Parliamentary Politics and Foreign Exchange Markets: The World According to GARCH.” International Studies Quarterly 50(1): 69-92.

Loayza, Norman V., Romain Rancière, Luis Servén, and Jaume Ventura. 2007. "Macroeconomic Volatility and Welfare in Developing Countries: An Introduction." The World Bank Economic Review 21(3): 343-357.

Longstaff, Francis A., Jun Pan, Lasse H. Pedersen, and Kenneth J. Singleton. 2011. "How Sovereign Is Sovereign Credit Risk?" American Economic Journal: Macroeconomics 3(2): 75-103.

Martínez, Juan, and Javier Santiso. 2003. "Financial Markets and Politics: The Confidence Game in Latin American Emerging Economies." International Political Science Review 24(3): 363-395.

Maxfield, Sylvia. 1997. Gatekeepers of Growth: The International Political Economy of Central Banking in Developing Countries. Princeton University Press.

McGillivray, Fiona, and Alastair Smith. 2008. Punishing the Prince: A Theory of Interstate Relations, Political Institutions, and Leader Change. Princeton, N.J.: Princeton University Press. 
McMenamin, Iain, Michael Breen, and Juan Muñoz-Portillo. 2016. "Comparative Politics and Quasi-Rational Markets." New Political Economy 21(6): 587-605.

Mengle, David. 2007. "Credit Derivatives: An Overview." Economic Review-Federal Reserve Bank of Atlanta Fourth Quarter: 1-24.

Mosley, Layna. 2003. Global Capital and National Governments. New York, NY: Cambridge University Press.

Mosley, Layna, Victoria Paniagua, and Erik Wibbels. 2020. "Moving Markets? Government Bond Investors and Microeconomic Policy Changes.” Economics \& Politics .

North, Douglass C., and Barry R. Weingast. 1989. "Constitutions and Commitment: The Evolution of Institutions Governing Public Choice in Seventeenth-Century England." The Journal of Economic History 49(4): 803-832.

Pástor, Luboš, and Pietro Veronesi. 2013. "Political Uncertainty and Risk Premia." Journal of Financial Economics 110(3): 520-545.

Pastor, Robert A. 1990. “Salinas Takes a Gamble.” New Republic 203(11/12): 27-32.

Pindyck, Robert S. 1991. "Irreversibility, Uncertainty, and Investment." Journal of Economic Literature 29(3): $1110-1148$.

Rigby, R. A., and D. M. Stasinopoulos. 2005. "Generalized Additive Models for Location, Scale and Shape." Journal of the Royal Statistical Society: Series C (Applied Statistics) 54(3): 507-554.

Rodrik, Dani. 1991. "Policy Uncertainty and Private Investment in Developing Countries." Journal of Development Economics 36(2): 229-242.

Saiegh, Sebastian M. 2009. “Coalition Governments and Sovereign Debt Crises." Economics \& Politics 21(2): 232-254.

Sattler, Thomas. 2013. “Do Markets Punish Left Governments?” The Journal of Politics 75(02): 343-356.

Schultz, Kenneth A., and Barry R. Weingast. 2003. "The Democratic Advantage: Institutional Foundations of Financial Power in International Competition.” International Organization 57(1): 3-42.

Shea, Patrick E., and Jonathan A. Solis. 2018. "Leaders, Tenure, and the Politics of Sovereign Credit." International Interactions 44(2): 294-320.

Simmons, Beth A. 1999. "The Internationalization of Capital." In Continuity and Change in Contemporary Capitalism, ed. Herbert Kitschelt, Peter Lange, Gary Marks, and John D. Stephens. New York: Cambridge University Press pp. 36-69.

Smyth, Gordon K. 1989. "Generalized Linear Models with Varying Dispersion." Journal of the Royal Statistical Society. Series B (Methodological) 51(1): 47-60.

Stasavage, David. 2003. Public Debt and the Birth of the Democratic State: France and Great Britain 1688-1789. Cambridge University Press.

Tomz, Michael. 2007. Reputation and International Cooperation: Sovereign Debt across Three Centuries. Princeton, NJ: Princeton University Press. 
Tomz, Michael, and Mark L.J. Wright. 2013. "Empirical Research on Sovereign Debt and Default." Annual Review of Economics 5(1): 247-272.

Vaaler, Paul M., Burkhard N. Schrage, and Steven A. Block. 2005. "Counting the Investor Vote: Political Business Cycle Effects on Sovereign Bond Spreads in Developing Countries." Journal of International Business Studies 36(1): 62-88.

Vaaler, Paul M., Burkhard N. Schrage, and Steven A. Block. 2006. "Elections, Opportunism, Partisanship and Sovereign Ratings in Developing Countries.” Review of Development Economics 10(1): 154-170.

Waisman, Maya, Pengfei Ye, and Yun Zhu. 2015. "The Effect of Political Uncertainty on the Cost of Corporate Debt." Journal of Financial Stability 16: 106-117.

Walter, Stefanie. 2009. "The Limits and Rewards of Political Opportunism: How Electoral Timing Affects the Outcome of Currency Crises." European Journal of Political Research 48(3): 367-96.

Xiong, Wei, and Hongjun Yan. 2010. "Heterogeneous Expectations and Bond Markets." The Review of Financial Studies 23(4): 1433-1466. 